\title{
Modelling and Prediction of Road Transportation Noise Pollution in Some Capital Cities in Eastern Nigeria by Use of Artificial Neural Network
}

\author{
Effiong O. Obisung*1 Aniefiok O. Akpan ${ }^{2} \quad$ Ubon E. Asuquo ${ }^{1}$ \\ 1.Department of Physics, University of Calabar, Calabar, Nigeria \\ 2.Department of Physics, Akwa Ibom State University, Ikot Akpanden, Mkpat Enin, Akwa Ibom State, Nigeria
}

\begin{abstract}
The study attempts to model and predict road transportation noise pollution in five capital cities in Eastern Nigeria. The capital cities are Calabar, Uyo, Umuahia, Owerri and Port Harcourt. Feed-forward neural network (FNN) with negative back-propagation algorithm was used to do this. The software used was NeuroXL. The ability of this software to handle multiple non-linear relationships makes it ideall y suited for this work. The input data used were total road traffic volume, road traffic mix, road traffic noise pollution response data, and distances from road centre-line to measurement points. The output data used was A-weighted energy mean sound level $\left(\mathrm{L}_{\mathrm{A}} \mathrm{eq}\right)$. Models based on this negative back- propagation neural network were trained, validated and tested using data collected. The performance of the model was tested by an error measure, root mean square error (RMSE). RMSE is low as expected, ranges from $1.007-1.814$, showing that the model is good for the prediction of road traffic noise data. The correlation between observed and predicted noise levels ( $L A e q)$ was also obtained, and ranges between +0.757 to +0.974 , showing that there is no significant difference between observed and predicted noise levels, thereby, proving the model accurate and reliable.
\end{abstract}

Keywords: Artificial neural network, back-propagation, road traffic noise modeling, road traffic noise prediction, NeuroXL software

DOI: $10.7176 / \mathrm{JEES} / 11-10-06$

Publication date:October $31^{\text {st }} 2021$

\subsection{Introduction}

Nigerian urban dwellers are excessively exposed to severe environmental/city noise pollution. The most disturbing city noise source, as generally established in the developing and developed urban communities being road transportation, as noise from it causes a lot of socio-psychological and physiological problems such as annoyance, sleeplessness, hearing loss, communication disturbances, speech intelligibility, cardiovascular disorders and other health problems [1 - 9]. The heterogeneous nature of urban environments, coupled with the characteristics of road transportation noise, their spatial, temporal and spectral variability, makes the matter of modeling and prediction of road transportation pollution a very complex and non-linear problem, to which the application of artificial neural networks becomes imperative. Artificial neural networks (ANNs) are widely used in road transportation noise modeling and prediction as a preference to more conventional statistical techniques, because ANNs are non-linear, relatively insensitive to noise data, perform reasonably well when limited data are available, and provide flexibility, accuracy and fault tolerance in changing environments [9-17].

\subsection{Materials and methods}

\subsection{Measurement sites}

One hundred (100) measurement sites were randomly selected from the five (5) Nigerian capital cities surveyed. Fifty (50) sites were chosen from road transportation high noise pollution zones, where heavy road transportation volume and dense traffic mix (composition) are experienced, on daily basis to serve as study group, while 50 sites were from low noise zones to serve as control group.

Fig. 1 shows map of Nigeria indicating the surveyed capital cities, while tables 1 - 5 show the description of the measurement sites.

\subsection{Materials for data collection}

\subsubsection{Materials for acoustic data collection}

A precision sound level meter, Bruel and Kjaer (B \& K), type 732 was used to assess road transportation noise levels at each measurement sites. Other materials used included measuring tape (to measure distance from the road centre line to the measurement points); stop watch/clock (to take sampling/measurement times); tally sheets (to record motor vehicle volume and motor vehicle mix during measurement/sampling times); and tripod stand (to support the sound level meter). 


\subsubsection{Materials for psycho-social data collection}

Subjective (psycho-social) responses of respondents exposed to intense road transportation noise were obtained by use of questionnaire items. The questionnaire was designed after Fields [18] with some variations to suit the objectives of this study. The questionnaire contains a number of noise response questions to help elicit the needed social noise data from respondents on road transportation noise-induced health problems such as sleeplessness, annoyance, hearing loss, auditory communication disturbance, and others. Information on effects of road transportation noise pollution on various health challenges has six (6) rating options: Extremely severe disturbance (ESD) with response rating of 6; Very severe disturbance (VSD) with rating of 5; Severe disturbance (SD) with rating of 4; Moderate disturbance (MD) with rating of 3; Little disturbance (LD) with rating of 2; and No disturbance (ND) with response rating of 1 . The questionnaire also contains information on some demographic/socio- economic variables such as: sex (male and female), age (15 years and above), marital status (single, married, divorced), educational level (primary, secondary, tertiary schools), occupation (student, civil/public servants, business/trader, artisan, jobless), occupational status (junior, senior, executive), income level (low, medium, high), among others.

\subsection{Methods of data collection}

\subsubsection{Methods for acoustical data collection}

A precision sound level meter was used to collect the road transportation noise levels in line with ISO 1996 - 1 and ISO 1996 - 2 standards [19, 20]. All measurements were done when motor vehicles (motorcycles/tricycles, cars/jeep, buses and trucks/trailers, etc) were moving past the measurement points. Readings of noise levels, background noise levels (BNLs) and A-weighted energy mean noise levels $\left(\mathrm{L}_{\text {Aeq }}\right)$ at each measurement point were taken every fifteen (15) minutes (sampling time or time rate) for a period of about 15 hours (7am - 10pm) daytime period, and 9 hours (10pm - 7am) nighttime period. Sound level meter (SLM) was held on a tripod stand with a microphone directly pointing toward noise source about $1.5-2.0 \mathrm{~m}$ high from the ground, and $3.5 \mathrm{~m}$ from reflecting surfaces. The distance between measurement point and road Centre line was $10-15 \mathrm{~m}$. Measurement sites were randomly selected to reflect roads with high and low transportation noise pollution levels, also away from airports, factories, construction sites and any other sources of heavy and intense noise other than motor vehicles. This was to prevent or reduce undue influence of these sources to road transportation noise levels. Total road traffic volume and road traffic mix (composition) were also recorded at each measurement sites. Tables 6-10 show observed and predicted LAeq data and mean road transportation volume per hour during recording time at daytime and nighttime periods in the surveyed capital cities.

\subsubsection{Methods for Psycho-social data collection}

Subjective (Psycho-social) responses of respondents exposed to intense road transportation noise pollution were obtained by use of road transportation noise pollution survey questionnaire (RTNPSQ) and analysed and evaluated. Persons who have literacy skills (reading and writing skills in English), who reside at the place for atleast three (3) years as at the time the survey took place, and who were upto 15 years and above by age, were given copies of the questionnaire to complete objectively and return to the researcher. These precautions were taken to help reduce information bias on the part of the respondents. Two thousand and five hundred $(2,500)$ persons were given copies of the questionnaire at road transportation high noise pollution sites, to serve as experimental group, while another 2,500 persons were given some copies of questionnaire at low noise pollution sites, to serve as control group. In all, the response rates at high and low noise pollution sites were $93.5 \%$ and $94.8 \%$ respectively.

\subsubsection{Artificial neural network training process}

Every neural network has input, hidden and output layers (nodes). Feed-forward neural network (FNN) and many other networks learn using back-propagation algorithm. The input data used in this study include total road traffic volume, road traffic composition (mix), distance from measurement point to road centre-line; and respondents' road traffic noise pollution-induced response data. The input data were divided into two sets - training (learning) data set and checking (testing) data set. Data points for road traffic high noise pollution sites were 486, 472, 454, 464 and 461 in Calabar, Uyo, Umuahia, Owerri and Port Harcourt cities respectively, while for road transportation low noise sites were 465, 480, 478, 476 and 471 in Calabar, Uyo, Umuahia, Owerri and Port Harcourt cities respectively. Table 11 shows summary of ANN training and checking data used for the study. Data points used for training ANN at high noise sites in Calabar, Uyo, Umuahia, Owerri and Port Harcourt cities were 301, 295, 297, 295 and 284 respectively, while at low noise sites were 296, 304, 295, 299 and 288 respectively. Also data points used for checking the validation of ANN at high noise sites in Calabar, Uyo, Umuahia, Owerri and Port Harcourt cities were 185, 177, 157, 169 and 177 respectively, while at low noise sites were 169, 176, 183, 177 and 183 respectively. With back-propagation, the input data were fed into the input layer to the hidden layer. Within the hidden layer they got summed, then processed by a non-linear function (usually either zero-based log sigmoid function or the hyperbolic tangent). The data were then finally multiplied by interconnection weights, then processed within the output layer to produce the neural network output. The output of the neural network was compared to the desired output, and the model error was computed. This error was then fed back (back-propagated) 
to the neural network and used to adjust the weights such that the model error decreased with each iteration, and the neural model got closer and closer in accuracy until the desired output was obtained, when the network no longer seemed to be learning, or an acceptable model error was reached. Fig. 2 shows a diagram demonstrating ANN training process [21], while table 12 shows summary of initial ANN training parameters. Table 13 shows the validation parameters of the ANN model.

\subsection{Data analysis/reductions}

The following noise measure or descriptor was used:

Energy mean A-weighted sound pressure level $\left(\mathrm{L}_{\text {Aeq }}\right)$ : This is mathematically expressed in Eqn. 1.

$\left.L_{\text {Aeq }}, 1 h r=10 \log _{10}\left[\sum_{N=1}^{N} f i \times 10^{\left(L_{i} / 10\right.}\right)\right] d B(A)$

Where $L_{i}=$ sound pressure level (in $d B(A)$ )

$f_{i}=$ fraction of observation time that $\mathrm{L}_{\mathrm{i}}$ is present (in seconds)

$\Sigma=$ summation symbol

The energy mean A-weighted sound pressure level, $\mathrm{L}_{\mathrm{Aeq}}$ is the energy average sound level occurring at a particular location over a given time interval. It is the most widely used measure to assess and regulate road and other transportation noise pollution because it correlates well with psycho-social responses of noise as well as its simplicity of use $[22,23]$ Root mean square error (RMSE): This is expressed in Eqn. 2

$R M S E=\sqrt{\frac{\sum\left(Y_{i}-X_{i}\right)^{2}}{N}}$

Correlation coefficient (r): This is expressed as in Eqn. 3

$$
r=\frac{\frac{\sum X Y-\bar{X} \cdot \bar{Y}}{N}}{\sigma_{X} \cdot \sigma_{Y}}
$$

$$
\begin{aligned}
& \text { where } \sigma_{X}=\sqrt{\frac{\sum^{2}}{N_{X}}-\bar{X}^{2}} ; \quad \sigma_{Y}=\sqrt{\frac{\sum^{2}}{N_{Y}}-\bar{Y}^{2}} \\
& Y_{i}=\text { predicted values } \\
& X_{i}=\text { observed values } \\
& N=\text { Number of data point } \\
& \bar{X}=\text { mean of observed duta } \\
& \bar{Y}=\text { mean of predicted data } \\
& \sigma_{x}=\text { standard deviation for observed data } \\
& \sigma_{y}=\text { standard deviation for predicted data }
\end{aligned}
$$

\subsection{Results}

The findings of this study are summarized in tables $6-10,13$ and Figs. $3-7$. Tables $6-10$ show observed (measured) and predicted (calculated) noise levels $\left(\mathrm{L}_{\text {Aeq }}\right)$ and mean road traffic volume and traffic mix at daytime and nighttime periods in the surveyed Nigerian cities. Table 13 shows the calculated validation parameters of the ANN model. Figs. $3 a-7$ a show correlation curves and $\mathrm{R}^{2}$-values between observed and predicted $\mathrm{L}_{\text {Aeq }}$, while Figs. $3 b-7 b$ show ANN performance curves for checking (testing) data for road traffic high and low noise pollution sites, indicating respondents' noise reactions against observed and predicted $\mathrm{L}_{\mathrm{Aeq}}$ at surveyed Nigerian cities.

\subsection{Discussion of Results}

From Tables $6-10$ the observed and predicted $\mathrm{L}_{\text {Aeq }}$ appear to be correlating well. They are found to be high, beyond the recommended World Health Organization's standard [24]. The L $\mathrm{L}_{\text {Aeq }}$ ranged from $87.1-98.5 \mathrm{~dB}(\mathrm{~A})$ (observed)in Calabar city high noise sites. Similar trends were observed in other surveyed cities. Such levels of noise are high enough to cause human annoyance, discomfort, sleeplessness, hearing loss, communication disturbances, among other physiological and psycho-social health disorders [9]. The mean road traffic volume per hour (VPH) is much as observed in tables $6-10$ at high noise sites. It was shown that noise level is a function of traffic volume. Percentage of heavy duty vehicles ranged from $9.1-20.3 \%$. This magnitude of motor vehicles is alarming [9, 24]. Table 13 shows the calculated parameters for ANN model validation. The root mean square is the ANN error measure used in validating the network. From table 13 RMSE is quite low, within the theoretical values acceptable for ANN model to be acceptable and accurate [25]. RMSE is a measure of the spread of observed values about the predicted values. A large RMSE means a poor model because of a large variance [25] while a small RMSE means a good ANN model. In this study the RMSE values range from $1.007-1.814$, a reasonably low error values, proving that the ANN model is accurate. The correlation values between observed and predicted $\mathrm{L}_{\text {Aeq, }}$, from table 13 , range from +0.592 to +0.950 showing that there is no significant difference between observed and predicted $\mathrm{L}_{\mathrm{Aeq}}$, further proving that the ANN model is accurate [9].

In order to certify the good results obtained with the developed ANN based prediction model, correlation 
values between observed and predicted $\mathrm{L}_{\mathrm{Aeq}}$ are shown in Figs. $3 \mathrm{a}-7 \mathrm{a}$ while Figs. $3 \mathrm{~b}-7 \mathrm{~b}$ display the ANN model performance curves of observed and predicted values of the output variables $\left(\mathrm{L}_{\text {Aeq }}\right)$ for all data used for the checking (testing) phase based on noise impact responses from respondents. From the results obtained, the proposed ANN based model has achieved prediction with a reasonably low RMSE, and has shown a great capacity for generalization. The neural network is capable of predicting, with considerable precision and accuracy, the sound pressure level $\left(\mathrm{L}_{\mathrm{Aeq}}\right)$ and even temporal and spectral composition of the different types of situations presented to the network [26].

\subsection{Conclusion}

Due to their well-known characteristics, the use of artificial neural networks to approach a complex problem of modelling and prediction of urban noise seemed highly recommended [9, 17]. Based on the results discussed in this paper this hypothesis is certified. The developed ANN based prediction model is capable of predicting, with great accuracy, road traffic noise levels as well as their temporal and spectral compositions in cities. In this study, the model developed is not only able to learn and predict those data presented during the training phase, but also is able, with great success, to predict noise data used for the testing phase, which inform about its great capacity of generalization. This goes to show that the model will not only be very useful for cities surveyed under this study, but also for other cities which have similar noise situations and characteristics [9, 26].

\subsection{Acknowledgements}

The authors are very grateful to all those who helped in data collection/collation.

\section{REFERENCES}

1. N. L. Carter. Transportation noise, sleep, and possible after-effects. Environmental International, 22. 105 116.

2. World Healt Organization - WHO. Burden of disease from environmental noise. Geneva, 2011a.

3. A. S. Stansfeld and M. P. Matheson. Noise pollution auditory effects on health. Oxford Journals, British Medical Bulletin, 68, 243 - 257, 2012.

4. D. R. Nandawar, D. K. Parbat, and S. K. Deshmukh. Study on residents perception and attitudes towards urban traffic noise in Nagpur city. $2^{\text {nd }}$ International Conference on emerging trends in engineering and technology. Naspur ICETET, 585 - 588, 2009.

5. M. U. Onuu. Road traffic noise in Nigeria: Measurement, analysis and evaluation of nuisance.

6. M. U. Onuu. Noise pollution in the urban environment:assessment of objectionable qualities of road traffic noise. Nigerian Journal of Physics, 12, 68 - 71; 2000a.

7. M. U. Onuu, and A. I. Menkiti. Analysis of Nigerian community response to road traffic noise. Journal of Science, Engineering and Technology, 3, 536 - 547; 1996.

8. E. O. Obisung, M. U. Onuu and A. I. Menkiti. Levels and spectra of aircraft noise and people's reactions in some Nigerian cities. Nigerian Journal of Physics 19 (2), 223 - 226, 2007.

9. E. O. Obisung. Acoustical investigation and prediction of road transportation noise pollution in some urban communities in Eastern Nigeria: A Ph. D Dissertation (Engineering Physics), Department of Physics, University of Calabar, Calabar, Nigeria, 2012.

10. M. Smith. Neural networks for statistical modelling. Van Nostrand Reinhold, ISBN 0-442- 01310-8, 1993.

11. J. Lawrence. Introduction to neural networks. California Scientific Software Press. ISBN $1-88315700-5$, 1994.

12. S. Haykin. Neural networks: a comprehensive foundation. Prentice Hall, ISBN $0-13-27-3350-1,1999$.

13. A. I. El - Mallawary, M. I. Abdallah and M. A. El - Gawad. Modeling of traffic noise pollution with neural networks. Journal of the Acoustic Society of America, 05 (2); 1335 - 1338, 1999.

14. A. Calixto, F. B. Diniz and P. H. T. Zannin. The statistical modelling of road traffic noise in urban setting. Cities 20 (1):23 - 29, 2003.

15. D. K. Parbat and P. B. Nagarnaik. Artificial neural network modelling of road transport noise descriptors. In preceedings of the $1^{\text {st }}$ International Conference on trends in engineering and Technology, ICETET' 08. IEEE Computer Society, Washington, D. C, USA, pp 1017 - 1024; 2008. Journal of Sound and Vibration, 233(3), $391-405,2000 b$.

16. K. Kumar, M. Parida, V. K. Katiya. Prediction of urban traffic noise using artificial neural network approach. Environmental Engineering and Management Journal, Gheorghe Asachi Technical University of Lasi, Romania, 2012.

17. H. R. Maier and G. C. Dandy. The effect of internal parameters and geometry on the performance of backpropagation neural networks: an empirical study. Environmental Modeling and Software, Vol. 13, No. 2, 193 $-209,1998$.

18. J. M. Fields. Effects of personal and situational variables upon noise annoyance in residential areas. Journal 
of the Acoustical Soc. Of Am; 93, 2753 - 2763; 1993.

19. ISO 1996 - 1. Acoustics-description, measurement and assessment of environmental basic quantities and assessment noise procedures.

20. ISO $1996-2$. Acoustics-description, measurement and assessment of environmental noise-Determination of environmental noise levels.

21. M. Smith. Neural networks for statistical modelling. Van Nostrand Reinhold, ISBN $0-442-01310-8$, 1993.

22. F. J. Langdon. Noise nuisance caused by road traffic noise in residential areas. Part 1. Journal of Sound and Vibration, 47, 265 - 282; 1976a.

23. D. Gottlob. Regulations for community noise. Noise/News International. Vol. 3, (4), 223 - 236; 1995.

24. WHO - World Health Organization. Guidelines for community noise: A complete, authoritative guide on effects of noise pollution on health. Switzerland, 1999.

25. R. Hyndman, J. Koehler and B. Anne. Another look at measures of forecast accuracy. International Journal of forecasting, $679-688 ; 2006$.

26. A. J. Torijia, D. P. Ruiz and A. Ramos-Ridao. Developing an artificial neural network for modelling and prediction of temporal structure and spectral composition of environmental noise in cities. University of Granada, Spain. www.intechopen.com. Retrieved 10 $0^{\text {th }}$ April, 2013.

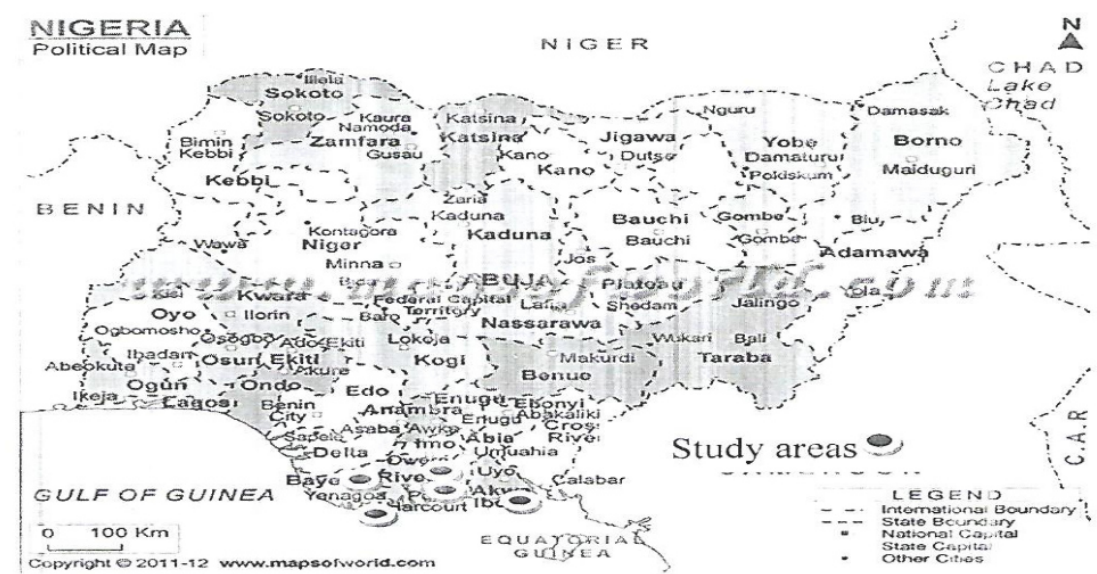

Fig. i: Map of Nigeria showing study areas.

Table 1: Codes, measurement sites and GPS readings for Calabar study area.

\begin{tabular}{|c|c|c|c|c|c|}
\hline \multicolumn{3}{|c|}{ Road transportation high noise pollution sites (HNPSs) } & \multicolumn{3}{|c|}{ Road transportation low noise pollution sites } \\
\hline Codes & Measurement sites & GPS & Codes & Measurement sites & GPS \\
\hline HCA 1 & Mbukpa Road & $5^{0} 10^{1} \mathrm{~N}, 7^{0} 05^{1} \mathrm{E}$ & LCA 1 & New Airport Road & $5^{1} 43^{1} \mathrm{~N}, 7^{0} 35^{1} \mathrm{E}$ \\
\hline $\begin{array}{l}\text { HCA } 2 \\
\text { HCA } 3\end{array}$ & $\begin{array}{l}\text { Mavne Avenue } \\
\text { Calabar Road }\end{array}$ & $\begin{array}{l}5^{0} 15^{1} \mathrm{~N}, 7^{0} 45^{1} \mathrm{E} \\
6^{0} \mathrm{O}^{1} \mathrm{~N}, 7^{0} 25^{1} \mathrm{E}\end{array}$ & $\begin{array}{l}\text { LCA } 2 \\
\text { LCA } 3\end{array}$ & $\begin{array}{l}\text { Anantigha Road } \\
\text { Edibe-Edibe Road }\end{array}$ & $\begin{array}{l}5^{0} 40^{1} \mathrm{~N}, 7^{0} 48^{1} \mathrm{E} \\
5^{0} 20^{1} \mathrm{~N}, 7^{0} 33^{1} \mathrm{E}\end{array}$ \\
\hline HCA 4 & Mount Zion Road & $6^{0} 17^{1} \mathrm{~N}, 7^{0} 30^{1} \mathrm{E}$ & LCA 4 & Jebs Road & $6^{0} 15^{1} \mathrm{~N}, 7^{0} 40^{1} \mathrm{E}$ \\
\hline HCA 5 & Ekpo Abasi Street & $6^{0} 20^{1} \mathrm{~N}, 7^{0} 45^{1} \mathrm{E}$ & LCA 5 & Iman Street & $6^{1} 17^{1} \mathrm{~N}, 8^{0} 10^{1} \mathrm{E}$ \\
\hline HCA 6 & Etta Agbo Road & $5^{0} 50^{1} \mathrm{~N}, 7^{0} 50^{1} \mathrm{E}$ & LCA 6 & MCC Road & $5^{1} 15^{1} \mathrm{~N}, 7^{0} 20^{1} \mathrm{E}$ \\
\hline HCA 7 & IBB Way & $5^{0} 35^{2} \mathrm{~N}, 7^{0} 40^{1} \mathrm{E}$ & LCA 7 & Otop Abasi Street & $5^{1} 19^{1} \mathrm{~N}, 7^{0} 35^{1} \mathrm{E}$ \\
\hline $\begin{array}{l}\text { HCA } 8 \\
\text { HCA } 9 \\
\text { HCA } 10\end{array}$ & $\begin{array}{l}\text { Atimbo Road } \\
\text { Ndidem Usang IsoRoad } \\
\text { Murtala Mohammed Highway }\end{array}$ & $\begin{array}{l}6^{0} 40^{1} \mathrm{~N}, 7^{0} 20^{1} \mathrm{E} \\
6^{0} 55^{1} \mathrm{~N}, 7^{0} 55^{1} \mathrm{E} \\
5^{0} 18^{1} \mathrm{~N}, 7^{0} 50^{1} \mathrm{E}\end{array}$ & $\begin{array}{l}\text { LCA } 8 \\
\text { LCA } 9 \\
\text { LCA } 10\end{array}$ & $\begin{array}{l}\text { Atekong drive } \\
\text { Diamond Hill } \\
\text { Old Odukpani Road }\end{array}$ & $\begin{array}{l}6^{1} 20^{1} \mathrm{~N}, 8^{0} 15^{1} \mathrm{E} \\
650^{1} \mathrm{~N}, 8^{0} 25^{1} \mathrm{E} \\
555^{1} \mathrm{~N}, 7^{0} 19^{1} \mathrm{E}\end{array}$ \\
\hline
\end{tabular}


Table 2: Codes, measurement sites and GPS readings for Uyo study area.

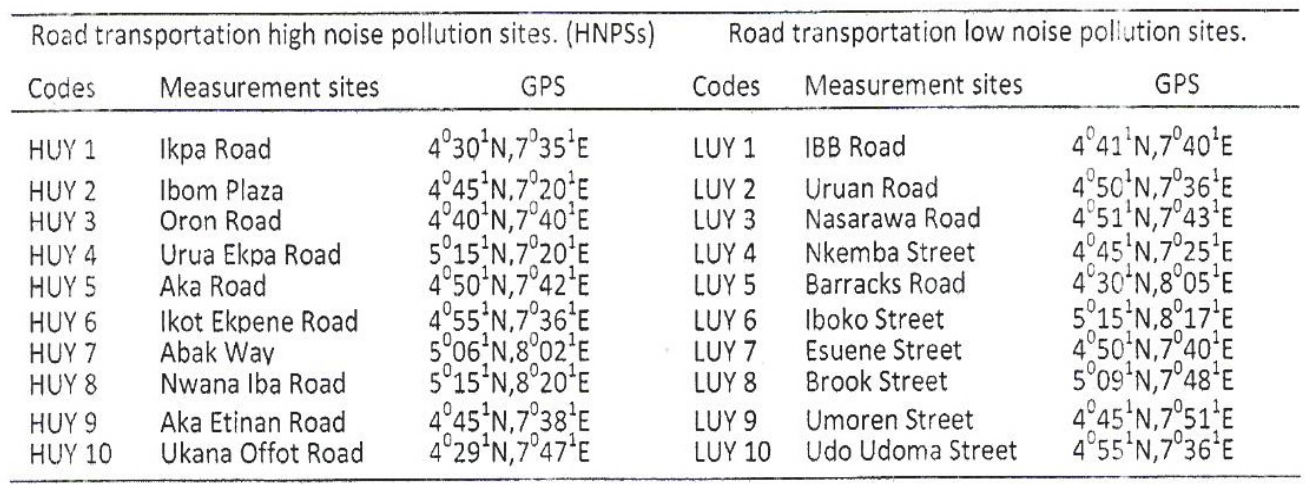

Table 3: Codes, measurement sites and GPS readings for Umuahia study area.

\begin{tabular}{|c|c|c|c|c|c|}
\hline \multicolumn{3}{|c|}{ Road transportation high noise pollution sites. } & \multicolumn{3}{|c|}{ Road transportation low noise pollution sites. } \\
\hline Codes & Measurement & GPS & Codes & Measurement & GPS \\
\hline HUM 1 & Umuwaya Road & $5^{0} 20^{1} \mathrm{~N}, 7^{0} 15^{1} \mathrm{E}$ & LUM 1 & Niger Road & $5^{0} 30^{-} \mathrm{N}, 7^{0} 20^{1} \mathrm{E}$ \\
\hline HUM 2 & Owerri Road & $5^{0} 24^{1} \mathrm{~N} \cdot 7^{0} 20^{1} \mathrm{E}$ & LUM 2 & Ibeku Road & $5^{0} 20^{-} \mathrm{N} \cdot 7^{0} 25^{1} \mathrm{E}$ \\
\hline $\begin{array}{l}\text { HUM } 3 \\
\text { HUM } 4\end{array}$ & Aba Road & & LUN & Calabar Road & $5^{\circ} 22 \mathrm{~N}, 7^{7} 22^{\circ} \mathrm{E}$ \\
\hline HUM 4 & Bende Road & $5^{0} 28^{1} \mathrm{~N}, 7^{0} 21^{1} \mathrm{E}$ & LUM 4 & Warri Street & $526 N, 7233^{2} E$ \\
\hline HUM 5 & Okwuro Road & $5^{0} 26^{1} \mathrm{~N} .7^{0} 20^{1} \mathrm{E}$ & LUM 5 & Kaduna Street & 521 N. $7^{7} 27^{1} \mathrm{E}$ \\
\hline HUM 6 & Umuahia Road & $531^{1} N, 7^{1} 30^{1} E$ & LUM 6 & Akanu Ibiam Road & $523 \mathrm{~N}, 724 \mathrm{E}$ \\
\hline HUM 7 & School Road & $5^{0} 20^{1} \mathrm{~N}, 7$ & LUM 7 & Azikiwe Road & $525 \mathrm{~N}, 70281 \mathrm{E}$ \\
\hline & Bank Road & $25^{1} \mathrm{E}$ & LUM 8 & Afara Road & $524^{\wedge} \mathrm{N} .730^{\circ} \mathrm{E}$ \\
\hline HUM 9 & Amakama Road & & LUM 9 & Okigwe Road & \\
\hline HUM 10 & Uzuakoli Road & $5^{0} 23$ & LUM 10 & Finbarrs Road & $5^{\circ} 28^{\circ}, 7^{7} 26^{\circ}$ \\
\hline
\end{tabular}

Table 4: Codes, measurement sites and GPS readings for Owerri study area.

\begin{tabular}{|c|c|c|c|c|c|}
\hline \multicolumn{3}{|c|}{ Road transportation high noise pollution sites. } & \multicolumn{3}{|c|}{ Road transportation low noise pollution sites. } \\
\hline Codes & Measurement & GPS & Codes & Measurement & GPS \\
\hline $\begin{array}{l}\text { HOW } 1 \\
\text { HOW } 2 \\
\text { HOW } 3 \\
\text { HOW } 4 \\
\text { HOW } 5 \\
\text { HOW } 6 \\
\text { HOW } 7\end{array}$ & $\begin{array}{l}\text { Amaieke Road } \\
\text { MCC Road } \\
\text { Douglas Road } \\
\text { Orlu Road } \\
\text { Imsu Road } \\
\text { Fire Service Road } \\
\text { Mbaise Road }\end{array}$ & $\begin{array}{l}5^{0} 35^{1} \mathrm{~N}, 6^{0} 55^{1} \mathrm{E} \\
6^{0} 20^{1} \mathrm{~N}, 7^{0} 15^{1} \mathrm{E} \\
6^{0} 15^{1} \mathrm{~N}, 7^{0} 20^{1} \mathrm{E} \\
5^{0} 50^{1} \mathrm{~N} \cdot 6^{0} 45^{1} \mathrm{E} \\
5^{0} 40^{1} \mathrm{~N}, 6^{0} 30^{1} \mathrm{E} \\
5^{0} 25^{1} \mathrm{~N}, 6^{0} 47^{1} \mathrm{E} \\
6^{0} 50^{1} \mathrm{~N}, 7^{0} 15^{1} \mathrm{E}\end{array}$ & $\begin{array}{l}\text { LOW } 1 \\
\text { LOW } 2 \\
\text { LOW } 3 \\
\text { LOW } 4 \\
\text { LOW } 5 \\
\text { LOW } 6 \\
\text { LOW } 7\end{array}$ & $\begin{array}{l}\text { School Road } \\
\text { World Bank Road } \\
\text { Tetlow Road } \\
\text { Rovce Road } \\
\text { West End Road } \\
\text { Ikenegbu Road } \\
\text { Prisons Road }\end{array}$ & $\begin{array}{l}6^{0} 21^{1} \mathrm{~N} .7^{0} 50^{1} \mathrm{E} \\
6^{0} 25^{1} \mathrm{~N}, 6^{0} 45^{1} \mathrm{E} \\
6^{0} 51^{1} \mathrm{~N}, 6^{0} 55^{1} \mathrm{E} \\
7^{0} 40^{1} \mathrm{~N} \cdot 6^{0} 10^{1} \mathrm{E} \\
7^{0} 36^{1} \mathrm{~N}, 6^{0} 15^{1} \mathrm{E} \\
6^{0} 40^{1} \mathrm{~N}, 6^{0} 25^{1} \mathrm{E} \\
6^{0} 50^{1} \mathrm{~N}, 6^{0} 36^{1} \mathrm{E}\end{array}$ \\
\hline $\begin{array}{l}\text { HOW } 8 \\
\text { HOW } 9 \\
\text { HOW } 10\end{array}$ & $\begin{array}{l}\text { Nekede Road } \\
\text { Wedtharl Road } \\
\text { Okigwe Road }\end{array}$ & $\begin{array}{l}7^{0} 10^{1} \mathrm{~N}, 7^{0} 20^{1} \mathrm{E} \\
5^{0} 25^{1} \mathrm{~N}, 6^{0} 50^{1} \mathrm{E} \\
6^{0} 26^{1} \mathrm{~N}, 7^{0} 20^{1} \mathrm{E}\end{array}$ & $\begin{array}{l}\text { LOW } 8 \\
\text { LOW } 9 \\
\text { LOW } 10\end{array}$ & $\begin{array}{l}\text { Asumpta Road } \\
\text { Mbari Road } \\
\text { Lagos Street }\end{array}$ & $\begin{array}{l}6^{0} 55^{1} \mathrm{~N}, 6^{0} 20^{1} \mathrm{E} \\
7^{0} 25^{1} \mathrm{~N}, 7^{0} 30^{1} \mathrm{E} \\
6^{0} 45^{1} \mathrm{~N}, 7^{\circ} 05^{1} \mathrm{E}\end{array}$ \\
\hline
\end{tabular}

Table 5: Codes, measurement sites, and GPS readings for Port Harccurt study area.

\begin{tabular}{|c|c|c|c|c|c|}
\hline \multicolumn{3}{|c|}{ Road transportation high noise pollution sites. } & \multicolumn{3}{|c|}{ Road transportation low noise pollution sites. } \\
\hline Codes & Measurement & GPS & Codes & Measurement sites & GPS \\
\hline $\begin{array}{ll}\text { HPH } & 1 \\
\text { HPH } & 2 \\
\text { HPH } & 3 \\
\text { HPH } & 4 \\
\text { HPH } & 5 \\
\text { HPH } & 6 \\
\text { HPH } & 7 \\
\text { HPH } & 8 \\
\text { HPH } 9 \\
\text { HPH } 10\end{array}$ & $\begin{array}{l}\text { Rumola Road } \\
\text { Choba Road } \\
\text { NTA Road } \\
\text { Atillerv Road } \\
\text { Rumokoro Road } \\
\text { Bori camp Road } \\
\text { Slaughter Road } \\
\text { Eleme Road } \\
\text { Water Line } \\
\text { Ada George Road }\end{array}$ & $\begin{array}{l}4^{0} 30^{1} \mathrm{~N}, 6^{0} 25^{1} \mathrm{E} \\
4^{0} 20^{1} \mathrm{~N}, 6^{0} 15^{1} \mathrm{E} \\
4^{0} 25^{1} \mathrm{~N} \cdot 6^{0} 20^{1} \mathrm{E} \\
4^{0} 15^{1} \mathrm{~N}, 6^{0} 21^{1} \mathrm{E} \\
4^{0} 35^{1} \mathrm{~N}, 6^{0} 40^{1} \mathrm{E} \\
4^{0} 40^{1} \mathrm{~N} \cdot 6^{0} 50^{1} \mathrm{E} \\
4^{0} 25^{1} \mathrm{~N}, 6^{0} 30^{1} \mathrm{E} \\
4^{0} 20^{1} \mathrm{~N} \cdot 6^{0} 26^{1} \mathrm{E} \\
4^{0} 50^{1} \mathrm{~N}, 6^{0} 45^{1} \mathrm{E} \\
4^{0} 36^{1} \mathrm{~N}, 6^{0} 35^{1} \mathrm{E}\end{array}$ & $\begin{array}{l}\text { LPH } 1 \\
\text { LPH } 2 \\
\text { LPH } 3 \\
\text { LPH } 4 \\
\text { LPH } 5 \\
\text { LPH } 6 \\
\text { LPH } 7 \\
\text { LPH } 8 \\
\text { LPH } 9 \\
\text { LPH } 10\end{array}$ & $\begin{array}{l}\text { Agip Road } \\
\text { Shell Gate Road } \\
\text { Mile } 1 \text { Market Road } \\
\text { Refinerv Wav } \\
\text { Borokiri } \\
\text { Airport Road } \\
\text { Garrison Road } \\
\text { Oroworoko Street } \\
\text { Port Harcourt Road } \\
\text { Bulletin Street }\end{array}$ & $\begin{array}{l}4^{0} 25^{1} \mathrm{~N}, 6^{0} 50^{1} \mathrm{E} \\
4^{0} 30^{1} \mathrm{~N}, 6^{0} 45^{1} \mathrm{E} \\
4^{0} 32^{1} \mathrm{~N}, 6^{0} 40^{1} \mathrm{E} \\
4^{0} 40^{1} \mathrm{~N}, 6^{0} 55^{1} \mathrm{E} \\
4^{0} 45^{1} \mathrm{~N}, 6^{0} 36^{1} \mathrm{E} \\
4^{0} 35^{1} \mathrm{~N} \cdot 6^{0} 30^{1} \mathrm{E} \\
4^{0} 33^{1} \mathrm{~N}, 6^{0} 52^{1} \mathrm{E} \\
4^{0} 46^{1} \mathrm{~N} \cdot 6^{0} 45^{1} \mathrm{E} \\
4^{0} 55^{1} \mathrm{~N}, 6^{0} 25^{1} \mathrm{E} \\
4^{0} 50^{1} \mathrm{~N}, 6^{0} 48^{1} \mathrm{E}\end{array}$ \\
\hline
\end{tabular}


Table 6: Statistics of measured (observed) and calculated (predicted) road transportation noise levels/indices obtained at both road transportation high and low noise pollution sites and corresponding road traffic volume per hour (VPH) during recording time at daytime and nighttime periods, under free flow conditions, in Calabar city.

\begin{tabular}{|c|c|c|c|c|c|c|c|c|c|c|c|c|c|}
\hline \multirow[t]{3}{*}{ Sites } & \multicolumn{2}{|c|}{$\begin{array}{l}\text { Measured } \\
\text { (observed) } \\
\text { noise levels } \\
( \pm 5.0 \mathrm{~dB}(\mathrm{~A})\end{array}$} & $\begin{array}{l}\text { Calculated } \\
\text { (predicted) } \\
\text { noise } \\
\text { levels/indices } \\
(\mathrm{dB}(\mathrm{A}))\end{array}$ & & & Me & n road & raffic $v$ & ume $\mathrm{p}$ & hour & (VPH) & & \\
\hline & & $\begin{array}{l}\text { LAeq } \\
\text { (SPL) }\end{array}$ & & 龸 & $\stackrel{\tilde{m}}{\check{n}}$ & 约 & 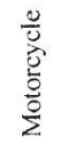 & $\begin{array}{l}\overline{0} \\
\frac{2}{0} \\
\stackrel{0}{0}\end{array}$ & 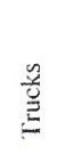 & $\stackrel{\bar{D}}{\mathscr{N}}$ & है & $\begin{array}{l}\frac{2}{3} \\
\frac{3}{3} \\
\frac{3}{2} \\
\sum\end{array}$ & $\begin{array}{l}\dot{0} \\
\frac{3}{0} \\
-1\end{array}$ \\
\hline & BNL, & Day & LAeq & \multicolumn{5}{|c|}{ Daytime } & \multicolumn{5}{|c|}{ Nighttime } \\
\hline \multicolumn{14}{|c|}{ Road transportation noise levels/indices and traffic volume per hour at road transportation high noise pollution sites } \\
\hline HCA I & 48.2 & 90.0 & 90.4 & 327 & 289 & $447^{\circ}$ & 538 & 1601 & 286 & 193 & 317 & 415 & 1211 \\
\hline $\mathrm{HCA} 2$ & 46.6 & 96.0 & 97.2 & 481 & 507 & 815 & 549 & 2352 & 150 & 275 & 283 & 361 & 1069 \\
\hline $\mathrm{HCA} 3$ & 41.3 & 87.0 & 87.1 & 416 & 503 & 613 & 432 & 1964 & 109 & 182 & 314 & 307 & 912 \\
\hline $\mathrm{HCA} 4$ & 45.2 & 94.0 & 95.8 & 294 & 476 & 588 & 469 & 1827 & 87 & 219 & 496 & 211 & 1013 \\
\hline HCA 5 & 50.4 & 99.0 & 97.0 & 313 & 394 & 601 & 456 & 1764 & 205 & 337 & 504 & 315 & 1361 \\
\hline $\mathrm{HCA} 6$ & 51.2 & 100.0 & 98.5 & 489 & 610 & 829 & 441 & 2369 & 189 & 223 & 461 & 209 & 1082 \\
\hline $\mathrm{HCA} 7$ & 43.1 & 89.0 & 88.2 & 391 & 533 & 565 & 602 & 2091 & 273 & 486 & 514 & 356 & 1629 \\
\hline HCA 8 & 40.4 & 92.0 & 90.0 & 503 & 642 & 471 & 459 & 3075 & 197 & 318 & 472 & 291 & 1278 \\
\hline HCA 9 & 41.7 & 97.0 & 98.0 & 367 & 470 & 386 & 373 & 1596 & 265 & 401 & 519 & 306 & 1491 \\
\hline $\mathrm{HCA} 10$ & 43.3 & 100.0 & 98.4 & 412 & 593 & 617 & 408 & 2139 & 214 & 396 & 502 & 179 & 1291 \\
\hline Total & & & & 3993 & 5017 & 5932 & 4727 & 19669 & 1975 & 3030 & 4382 & 2950 & 12337 \\
\hline$\%$ & & & & 20.3 & 25.5 & 30.2 & 24.0 & 100.0 & 16.0 & 246 & 35.5 & 23.9 & 100.0 \\
\hline \multicolumn{14}{|c|}{ Road transportation noise levels/indices and traffic volume per hour at road transportation low noise pollution sites } \\
\hline LCA I & 35.5 & $\% 0.0$ & 70.4 & 81 & 176 & 223 & 230 & 710 & 34 & 51 & 113 & 15 & 213 \\
\hline LCA 2 & 40.7 & 72.0 & 73.2 & 179 & 217 & 319 & 236 & 951 & 100 & 67 & 161 & 24 & 352 \\
\hline LCA 3 & 44.4 & 79.0 & 78.5 & 153 & 291 & 306 & 221 & 971 & 89 & 82 & 185 & 17 & 373 \\
\hline $\mathrm{LCA} 4$ & 43.3 & 76.0 & 74.6 & 102 & 283 & 291 & 347 & 923 & 91 & 69 & 87 & 30 & 277 \\
\hline LCA 5 & 42.4 & 74.0 & 72.2 & 89 & 106 & 204 & 233 & 632 & 65 & 53 & 92 & 11 & 221 \\
\hline LCA 6 & 45.6 & 80.0 & 80.0 & 164 & 214 & 301 & 325 & 1004 & 68 & 97 & 193 & 8 & 366 \\
\hline LCA 7 & 54.7 & 81.0 & 80.2 & 106 & 215 & 199 & 362 & 882 & 72 & 103 & 78 & 23 & 276 \\
\hline LCA 8 & 48.7 & 79.0 & 80.1 & 211 & 277 & 218 & 268 & 974 & 79 & 92 & 107 & 18 & 296 \\
\hline LCA 9 & 46.1 & 78.0 & 77.5 & 67 & 186 & 173 & 316 & 743 & 34 & 104 & 86 & 16 & 240 \\
\hline LCA 10 & 57.2 & 74.0 & 72.0 & 133 & 239 & 247 & 290 & 909 & 46 & 89 & 114 & 39 & 288 \\
\hline Total & & & & 1285 & 2204 & 2481 & 2728 & 8698 & 678 & 807 & 1216 & 201 & 2902 \\
\hline$\%$ & & & & 14.8 & 25.3 & 28.5 & 31.4 & 100.0 & 23.4 & 27.8 & 41.9 & 6.9 & 100.0 \\
\hline
\end{tabular}


Table 7: Statistics of measured (observed) and calculated (predicted) road transportation noise levels/indices obtained at both road transportation high and low noise pollution sites and corresponding road traffic volume per hour ( $\mathrm{PH}$ ) during recording time at daytime and nighttime periods, under free flow conditions. in Uyo city.

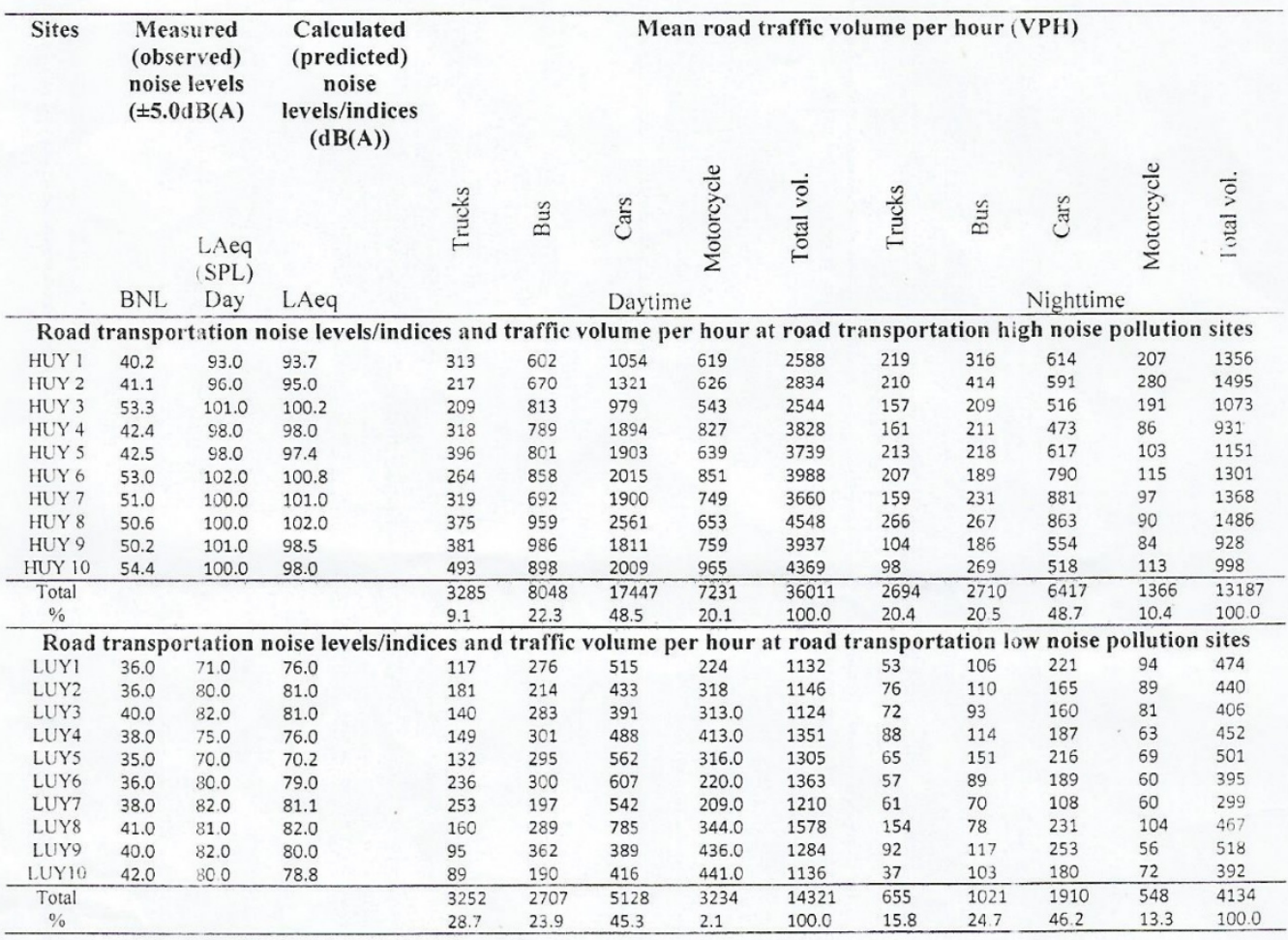


Table 8: Statistics of measured (observed) and calculated (predicted) road transportation noise levels/indices obtained at both road transportation high and low noise pollution sites and corresponding roac traffic volume per hour (VPH) during recording time at daytime and nighttime periods, under free flow conditions, in Umuahia city.

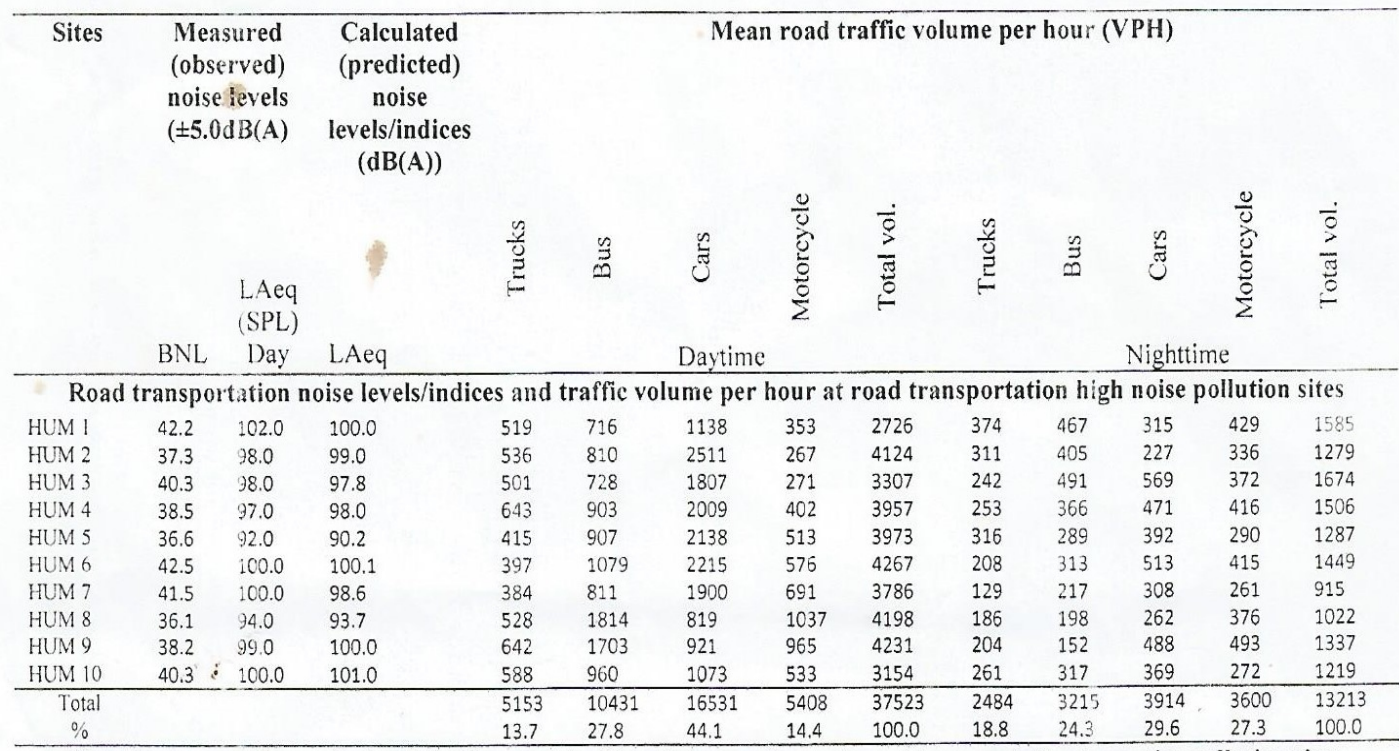

Road transportation noise levels/indices and traffic volume per hour at road transportation low noise pollution sites

\begin{tabular}{|c|c|c|c|c|c|c|c|c|c|c|c|c|c|}
\hline LUM I & 34.3 & 79.0 & 80.0 & 83 & 225 & 316 & 254 & 878 & 121 & 157 & 206 & 279 & 763 \\
\hline LUM 2 & 30.4 & 76.0 & 75.2 & 127 & 231 & 274 & 196 & 828 & 163 & 131 & 184 & 283 & 761 \\
\hline LUM 3 & 33.2 & 78.0 & 80.0 & 133 & 198 & 281 & 175 & 787 & 117 & 246 & 261 & 177 & 801 \\
\hline LUM 4 & 32.1 & 74.0 & 72.0 & 241 & 266 & 368 & 193 & 1068 & 89 & 175 & 237 & 206 & 707 \\
\hline LUM 5 & 36.1 & 35.0 & 82.0 & 319 & 183 & 357 & 201 & 1060 & 103 & 138 & 266 & 154 & 661 \\
\hline I.UM 6 & 30.6 & 76.0 & 76.0 & 106 & 217 & 493 & 164 & 980 & 76 & 131 & 302 & 146 & 655 \\
\hline LUM 7 & 35.7 & 78.0 & 80.0 & 92 & 304 & 217 & 190 & 803 & 81 & 216 & 103 & 127 & 527 \\
\hline LUM 8 & 36.5 & 82.0 & 80.0 & 173 & 213 & 109 & 367 & 862 & 65 & 103 & 98 & 138 & 404 \\
\hline LUM 9 & 38.4 & 72.0 & 70.0 & 126 & 257 & 213 & 281 & 877 & 73 & 115 & 279 & 200 & 667 \\
\hline LUM 10 & 30.3 & 70.0 & 68.5 & 191 & 299 & 216 & 393 & 1099 & 102 & 176 & 118 & 233 & 629 \\
\hline $\begin{array}{c}\text { Total } \\
\%\end{array}$ & & & & 1591 & 2393 & 2844 & 2414 & 9242 & 990 & $\begin{array}{l}1583 \\
215\end{array}$ & $\begin{array}{l}2954 \\
40.1\end{array}$ & $\begin{array}{l}1843 \\
25.0\end{array}$ & $\begin{array}{l}7316 \\
1000\end{array}$ \\
\hline
\end{tabular}


Table 9: Statistics of measured (observed) and calculated (predicted) road transportation noise levels/indices obtained at both road transportation high and low noise pollution sites and corresponding road traffic volume per hour (VPH) during recording time at daytime and nighttime periods, under free flow conditions, in Owerri city.

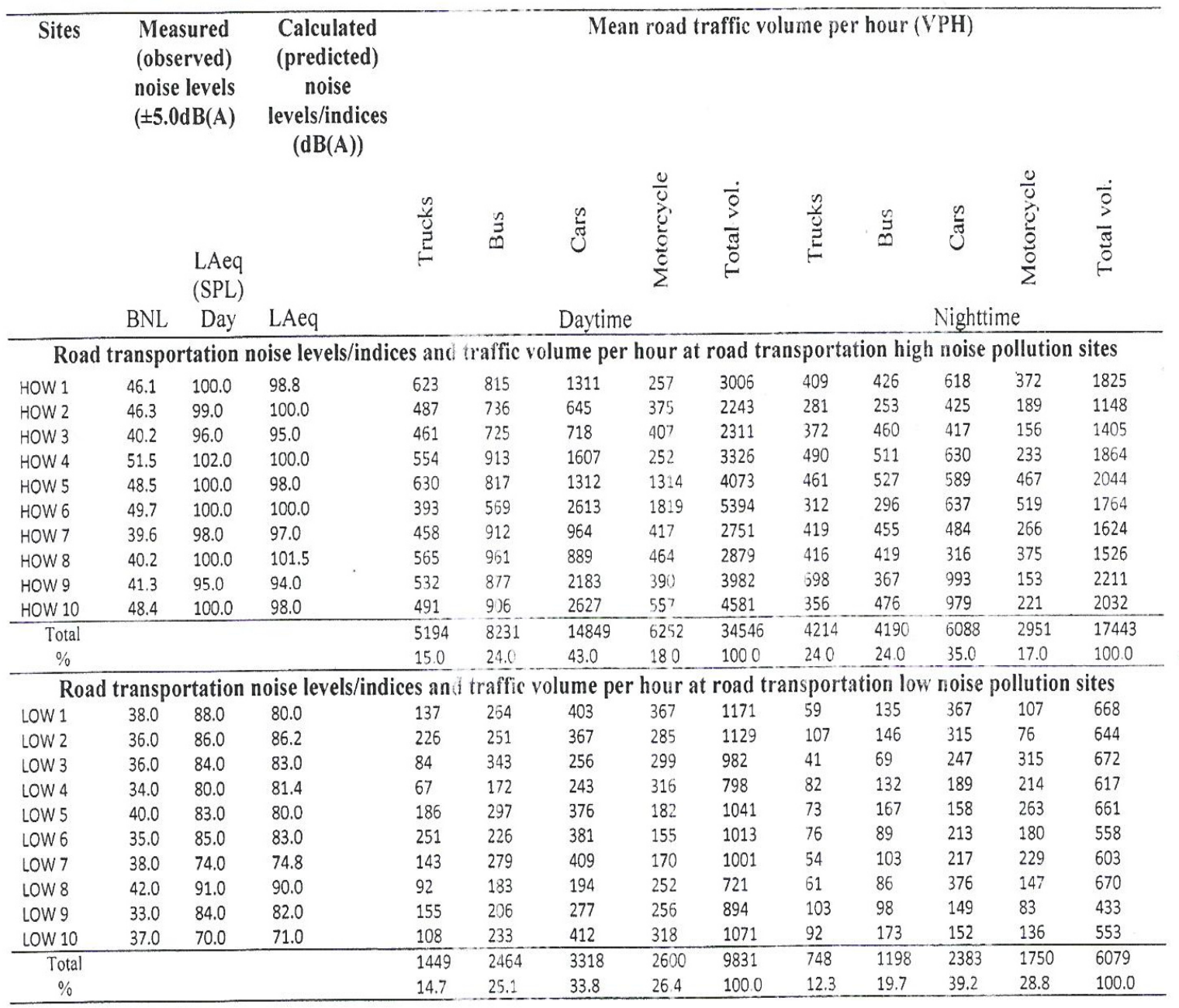


Table 10: Statistics of measured (observed) and calculated (predicted) road transportation noise levels/indices obtained at both road transportation high and low noise pollution sites and corresponding road tratfic volume per hour (VPH) during recording time at dxytime and nighttime periods, under free flow conditions, in Port Harcourt city

\begin{tabular}{|c|c|c|c|c|c|c|c|c|c|c|c|c|c|}
\hline \multirow[t]{2}{*}{ Sites } & \multicolumn{2}{|c|}{$\begin{array}{l}\text { Measured } \\
\text { (observed) } \\
\text { noise levels } \\
( \pm 5.0 \mathrm{~dB}(\mathrm{~A})\end{array}$} & Calculated & \multicolumn{10}{|c|}{ Mean road traffic volume per hour (VPH) } \\
\hline & \multicolumn{2}{|c|}{$\begin{array}{cc} & \text { LAeq } \\
& \text { (SPL) } \\
\text { BNL } \quad \text { Day }\end{array}$} & LAeq & $\stackrel{\tilde{e}}{\stackrel{\tilde{e}}{\mathrm{E}}}$ & $\stackrel{9}{9}$ & $\begin{array}{l}\text { 坣 } \\
\text { Daytime }\end{array}$ & $\begin{array}{l}\frac{2}{0} \\
\frac{2}{0} \\
\vdots \\
\vdots \\
\vdots\end{array}$ & 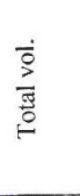 & 总 & 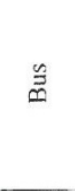 & \multicolumn{2}{|c|}{ 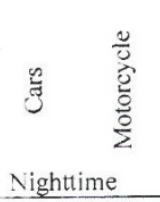 } & $\begin{array}{l}\dot{0} \\
\frac{2}{5} \\
\frac{5}{0}\end{array}$ \\
\hline \multicolumn{14}{|c|}{ Road transportation noise levels/indices anc traffic volume per hour at road transportation high aoise pollution sites } \\
\hline $\begin{array}{l}\mathrm{HPH} 1 \\
\mathrm{HPH} 2\end{array}$ & 49.7 & 100.0 & 99.0 & 576 & 615 & 2413 & 557 & 4161 & 283 & .376 & 615 & 268 & 1542 \\
\hline $\begin{array}{l}\mathrm{HPH} 2 \\
\mathrm{HPH} 3\end{array}$ & 38.6 & 98.0 & 96.0 & 513 & 728 & 3116 & 583 & 4940 & 326 & 384 & 1017 & 203 & 1930 \\
\hline $\begin{array}{l}\mathrm{HPH} 3 \\
\mathrm{HPH} 4\end{array}$ & 39.2 & 98.0 & 97.0 & 581 & 784 & 1969 & 674 & 4008 & 334 & 469 & 618 & 217 & 1638 \\
\hline $\begin{array}{l}\mathrm{HPH} 4 \\
\mathrm{HPH} 5\end{array}$ & 39.2 & 99.0 & 100.0 & 494 & 516 & 2337 & 465 & 3912 & 276 & 291 & 813 & 278 & 1658 \\
\hline HPH 5 & 48.6 & 100.0 & 100.3 & 387 & 539 & 918 & 452 & 2296 & 309 & 415 & 406 & 216 & 1346 \\
\hline $\mathrm{HPH} 6$ & 49.5 & 101.0 & 99.8 & 392 & 557 & 876 & 663 & 2488 & 107 & 372 & 235 & 448 & 1157 \\
\hline $\mathrm{HPH} 7$ & 48.5 & 100.0 & 98.6 & 618 & 473 & 1779 & 488 & 3358 & 269 & 253 & 365 & 338 & 1225 \\
\hline HPH 8 & 45.3 & 96.0 & 95.0 & 621 & BE 9 & 2275 & 426 & 4191 & 281 & 365 & 338 & 175 & 1159 \\
\hline $\mathrm{HPH} 9$ & 49.1 & 100.0 & 98.0 & 593 & 719 & 1866 & 591 & 3769 & 296 & 274 & 249 & 490 & 1309 \\
\hline $\mathrm{HPH} 10$ & 48.2 & 100.0 & 98.5 & 477 & $3 C 4$ & 2913 & 604 & 4798 & 361 & 387 & 886 & 344 & 1978 \\
\hline $\begin{array}{c}\text { Total } \\
\%\end{array}$ & & & & 5252 & $6704^{-}$ & 20462 & 5503 & 37921 & 2842 & 3586 & 5540 & 2942 & 14910 \\
\hline$\%$ & & & & 13.8 & 17.7 & 54.0 & 14.5 & 100.0 & 19.1 & 24.1 & 37.1 & 19.7 & 100.0 \\
\hline \multicolumn{14}{|c|}{ Road transportation noise levels/indices an traffic volume per hour at road transportation low noise pollution sites } \\
\hline LPH 1 & 36.5 & 76.0 & 76.6 & 388 & 276 & 1533 & 366 & 2563 & 183 & 89 & 615 & 178 & 1045 \\
\hline $\mathrm{LPH} 2$ & 34.4 & 80.0 & 79.0 & 269 & 453 & 927 & 257 & 1906 & 107 & 226 & 538 & 203 & 1074 \\
\hline LPH 3 & 36.3 & 83.0 & 82.6 & 371 & 464 & 508 & 341 & 1684 & 223 & 278 & 264 & 185 & 950 \\
\hline LPH 4 & 43.2 & 86.0 & 86.4 & 383 & 360 & 871 & 363 & 1977 & 217 & 180 & 356 & 152 & 905 \\
\hline LPH 5 & 38.1 & 77.0 & 76.0 & 262 & 451 & 562 & 377 & 1652 & 182 & 277 & 289 & 216 & 964 \\
\hline LPH 6 & 39.5 & 79.0 & 78.0 & 280 & 337 & 557 & 382 & 1556 & 124 & 130 & 227 & 170 & 651 \\
\hline $\mathrm{LPH} 7$ & 40.3 & 85.0 & 84.5 & 263 & $3 E 7$ & 380 & 247 & 1257 & 215 & 169 & 172 & 143 & 699 \\
\hline LPH 8 & 32.4 & 75.0 & 73.0 & 224 & 299 & 492 & 286 & 1301 & 98 & 156 & 303 & 127 & 684 \\
\hline LPH 9 & 39.2 & 84.0 & 82.0 & 317 & 386 & 1075 & 192 & 1970 & 276 & 204 & 429 & 86 & 995 \\
\hline LPH 10 & 35.3 & 80.0 & 78.0 & 286 & 473 & 1169 & 374 & 2392 & 172 & 225 & 618 & 168 & 1183 \\
\hline Total & & & & 3043 & 3866 & 8074 & 3185 & 18168 & 1777 & 1924 & 3811 & 1638 & 9140 \\
\hline$\%$ & & & & 16.7 & 21.4 & 44.4 & 17.5 & 100.0 & 19.4 & 21.0 & 41.7 & 17.9 & 100.0 \\
\hline
\end{tabular}

Table 11: Summary ${ }^{\circ}$ ANN training and checking data used for the study

\begin{tabular}{llllllllllll}
\hline Data & \multicolumn{3}{c}{ Calabar } & \multicolumn{2}{c}{ UYo } & \multicolumn{2}{c}{ Umuahia } & \multicolumn{2}{c}{ Owerri } & \multicolumn{2}{c}{ Port } \\
& HCA & LCA & HUY & LUY & HUM & LUM & HOW & LOW & HPH & LPH \\
\hline \multirow{2}{*}{ Data points } & 486 & 465 & 472 & 480 & 454 & 478 & 464 & 476 & 461 & 471 \\
Training data & 301 & 296 & 295 & 304 & 297 & 295 & 295 & 299 & 284 & 288 \\
Checking data & 185 & 169 & 177 & 176 & 183 & 157 & 169 & 177 & 183 & 177 \\
\hline
\end{tabular}

Table 13: $\quad$ Statistics for validation of the ANN model

\begin{tabular}{|c|c|c|c|c|c|c|c|c|c|c|}
\hline \multirow[t]{3}{*}{ Statistics } & \multicolumn{10}{|c|}{ Calculated values } \\
\hline & Cals & bar & Uy & & $\mathrm{Lmu}$ & ahia & & erri & Port $\mathrm{H}$ & rcourt \\
\hline & HNPS & LNPS & H.PS & LNPS & HNPS & LNPS & HNPS & LNPS & HNPS & LNPS \\
\hline Root mean square error (RMSE) & 1.310 & 1.007 & 1.385 & 1.109 & 1.155 & 1814 & 1.358 & 1538 & 1.332 & 1.295 \\
\hline Mean observed data $(\overline{O B})$ & 94.400 & 76.300 & 98.900 & 78.900 & 98000 & 77.00 & 99.000 & 82.500 & 99.200 & 80.500 \\
\hline Mean predicted data $(\overline{P R})$ & 93.980 & 75.970 & 98.460 & 78.510 & 97830 & 76.37 & 98.200 & 82.000 & 98.220 & 79.550 \\
\hline $\begin{array}{l}\text { Standard deviation for Observed } \\
\text { data }\left(\sigma_{O B}\right)\end{array}$ & 4.499 & 3.490 & 2.587 & 3.673 & 2.864 & 4243 & 2.000 & 6004 & 1.400 & 3.667 \\
\hline $\begin{array}{l}\text { Standard deviation for predicted } \\
\text { data }\left(\sigma_{P R}\right)\end{array}$ & 4.310 & 3720 & 5.) 21 & 3.398 & 3.185 & 4555 & 1.061 & 6137 & 1.654 & 3.908 \\
\hline t-test $(t)$ & 0.213 & 0) $2(4$ & 0.138 & 0.552 & (1) 126 & 0320 & 1,446 & 0 184 & 1.430 & 0.561 \\
\hline $\begin{array}{l}\text { Correlation between observed and } \\
\text { predicted data }(r)\end{array}$ & +0.962 & $40.75^{\circ}$ & +1) 843 & +0.846 & +0937 & +1) 927 & +0.847 & $+097 !$ & +0847 & +0.974 \\
\hline
\end{tabular}


Table 12: $\quad$ Summary of initial ANN training parameters.

\begin{tabular}{lll}
\hline S/N & Parameters & Values \\
\hline 1 & Initial weight & 0.3 \\
2 & Learning rate & 0.3 \\
3 & Momentum & 0.6 \\
4 & Activation function & Zero-based log sigmoid function \\
5 & Maximum number of epochs & 3000 \\
6 & Minimum weight & Range of 0.001 and 0.0001 \\
7 & Number of neurons in the hidden layer & 0 or 1 \\
\hline
\end{tabular}

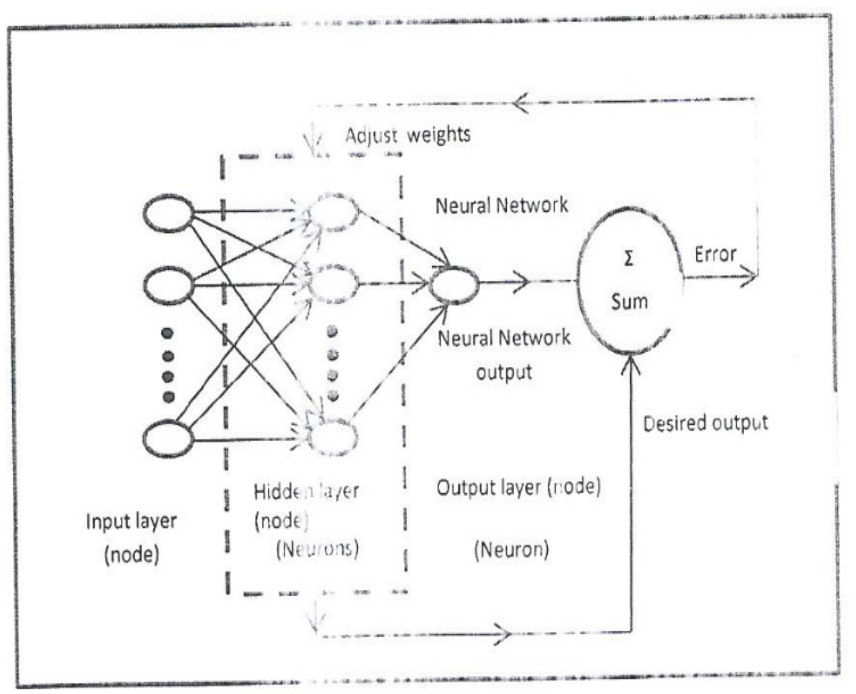

Fig. 2: Multilayer Pe coptron (MLP) - type of supervised neural network demonstrating tieura network training (learning) process. 


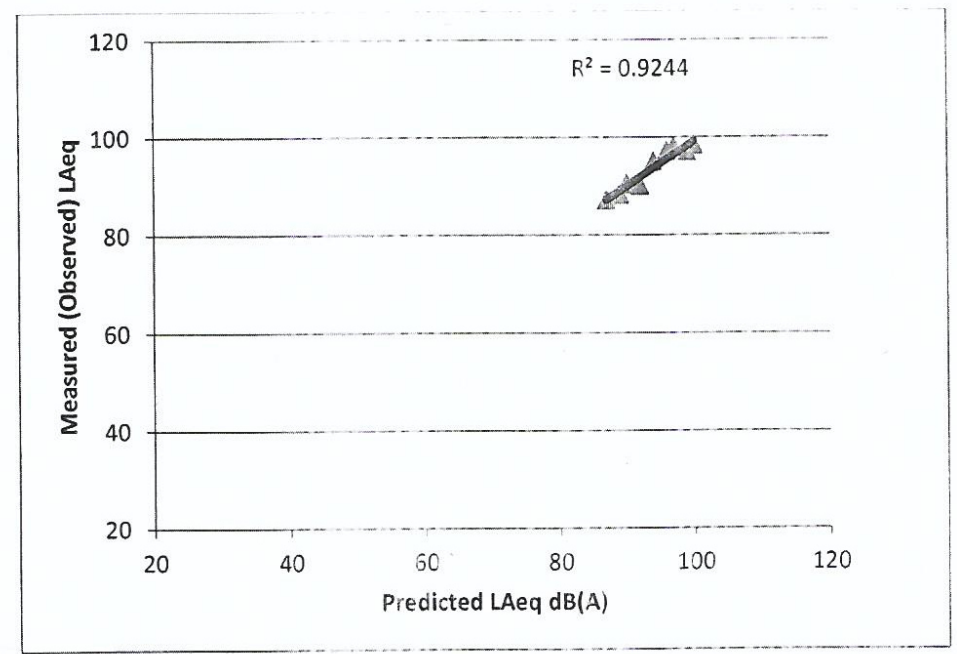

(a) HCA High traffic

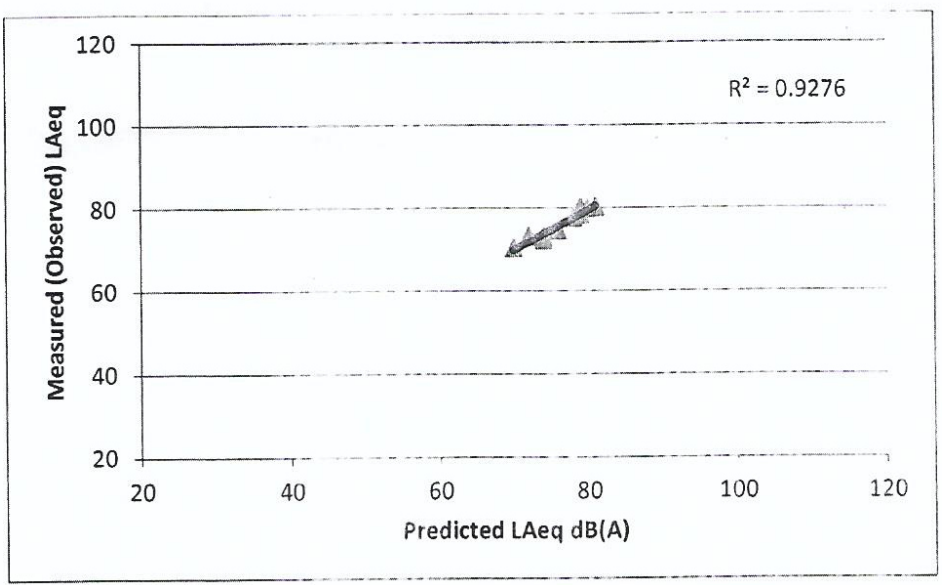

(b) LCA Low traffic

Fig. 3a: Correlation curves of observed LAeq versus predicted LAeq for study Calabar high and low study areas 


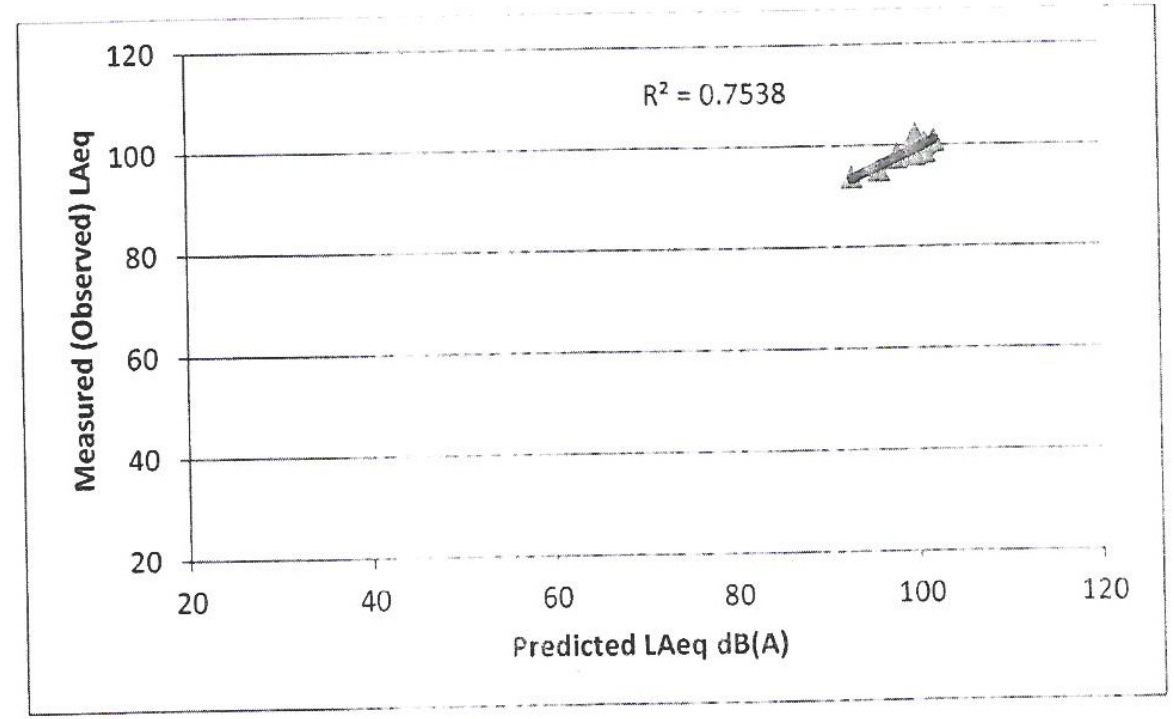

(a) HUY High traffic

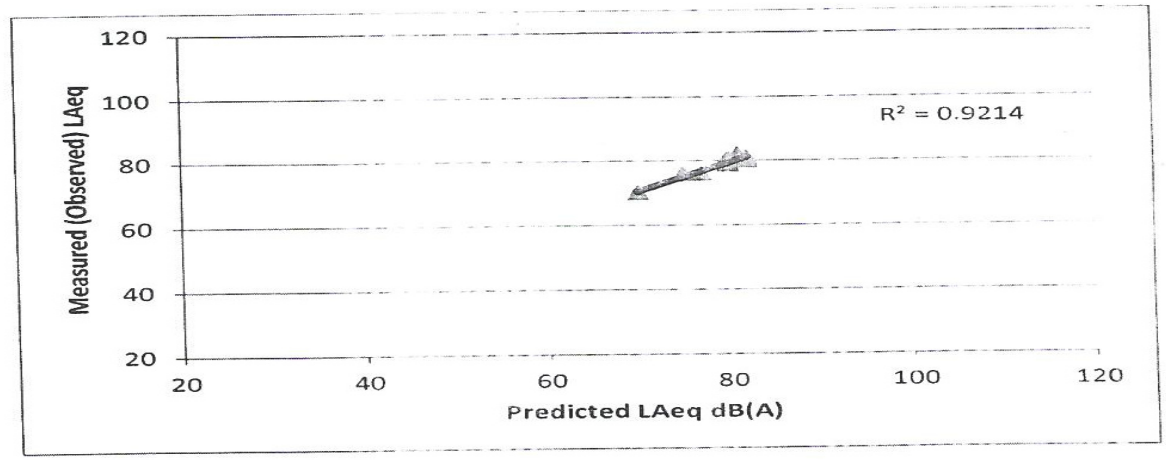

(b) LUY Low traffic

Fig. 4a: Correlation curves of observed L.Aeq versus predicted LAeq for study Uyo high and low study areas. 


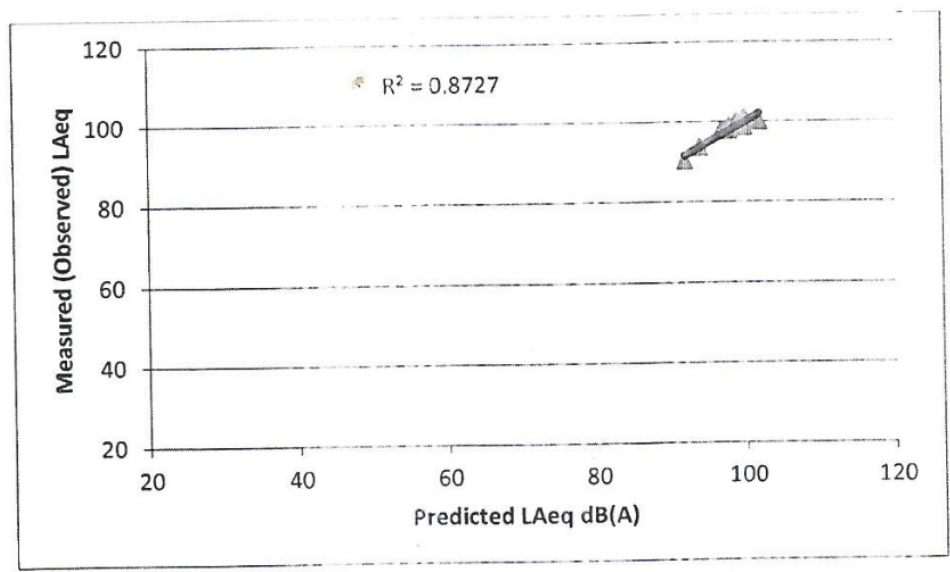

(a) HUM High traffic

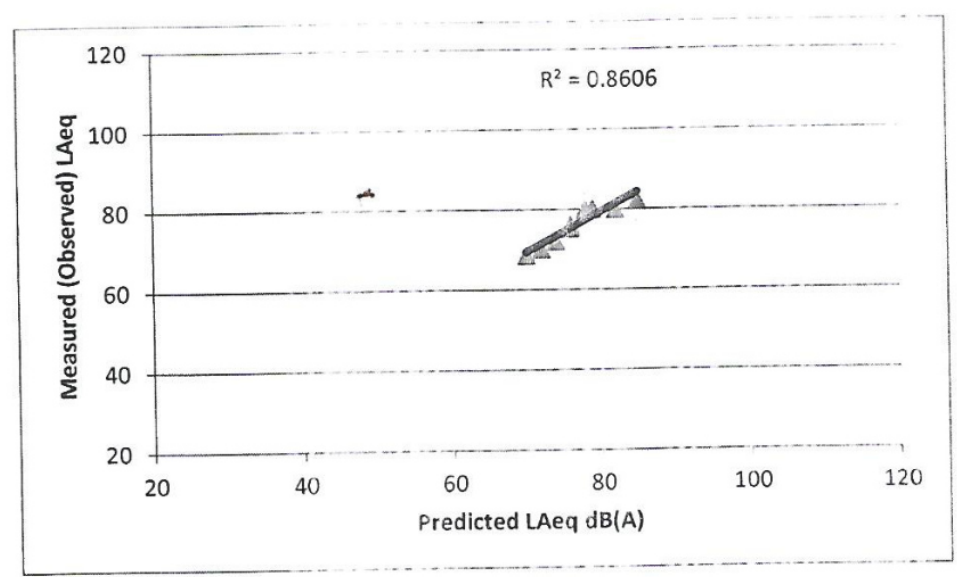

(b)LUM Low traffic

Fig. 5a: Correlation curves of obs ærved L.A.eq versus predicted LAeq for study Umuahia high and low study areas. 


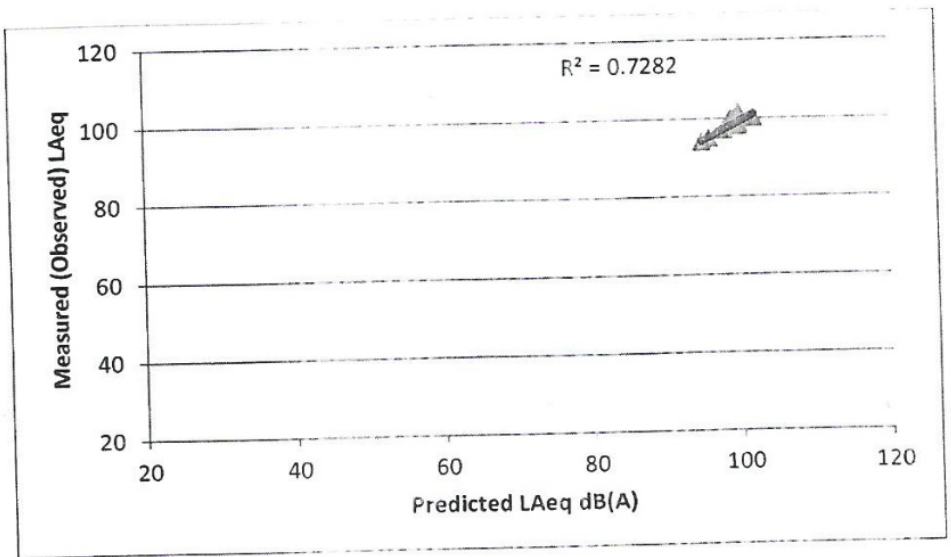

(a) HOW High traffic

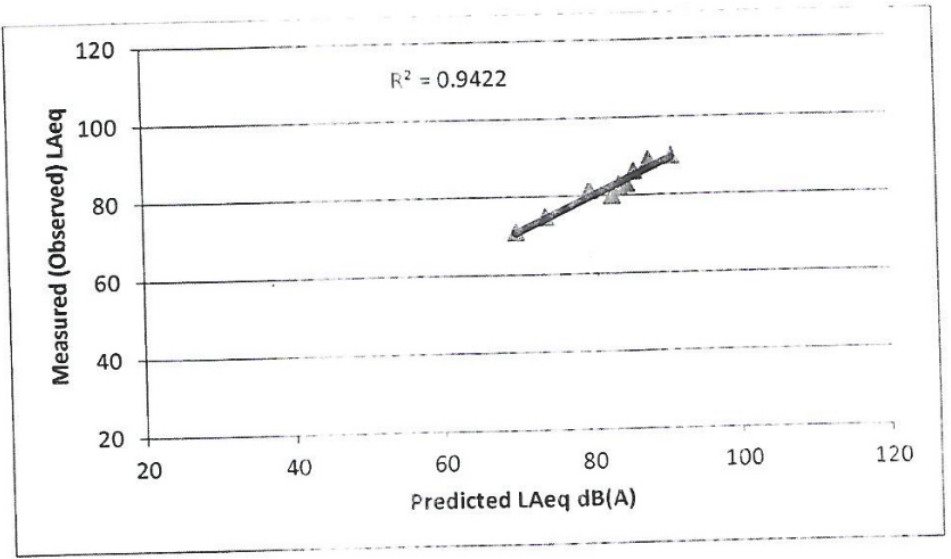

(b) LOW-Low traffic

Fig. 6a: Correlation curves of obse:ved LAeq versus predicted LAeq for study Owerri high and low study areas. 


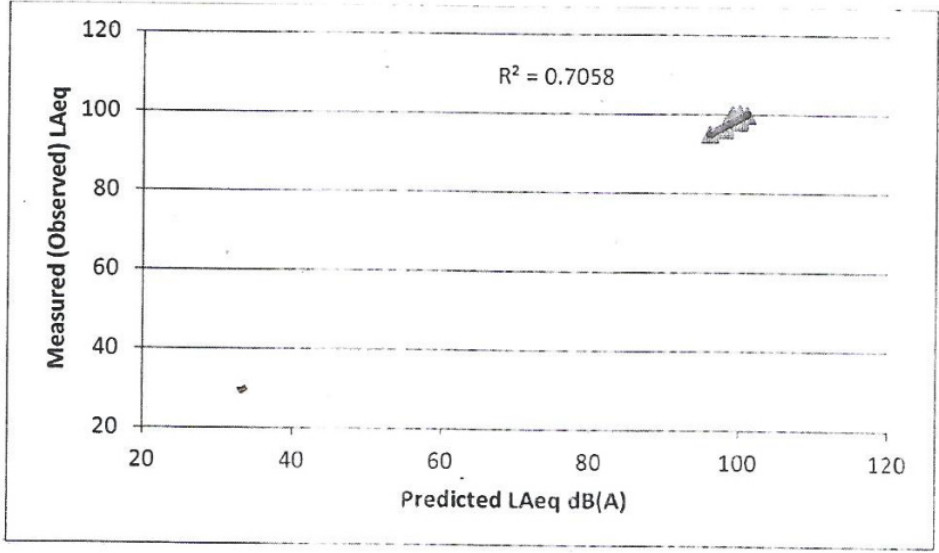

(a) HPH High traffic

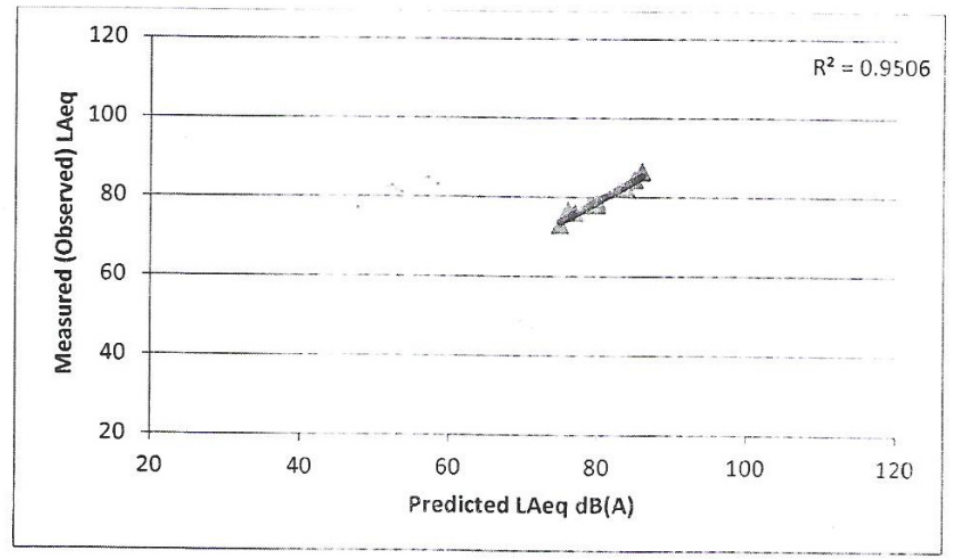

(b) LPH Low traffic

Fig. 7a: Correlation curves of obs ved LAeq versus predicted LAeq for study Port Harcourt high and low study areas. 


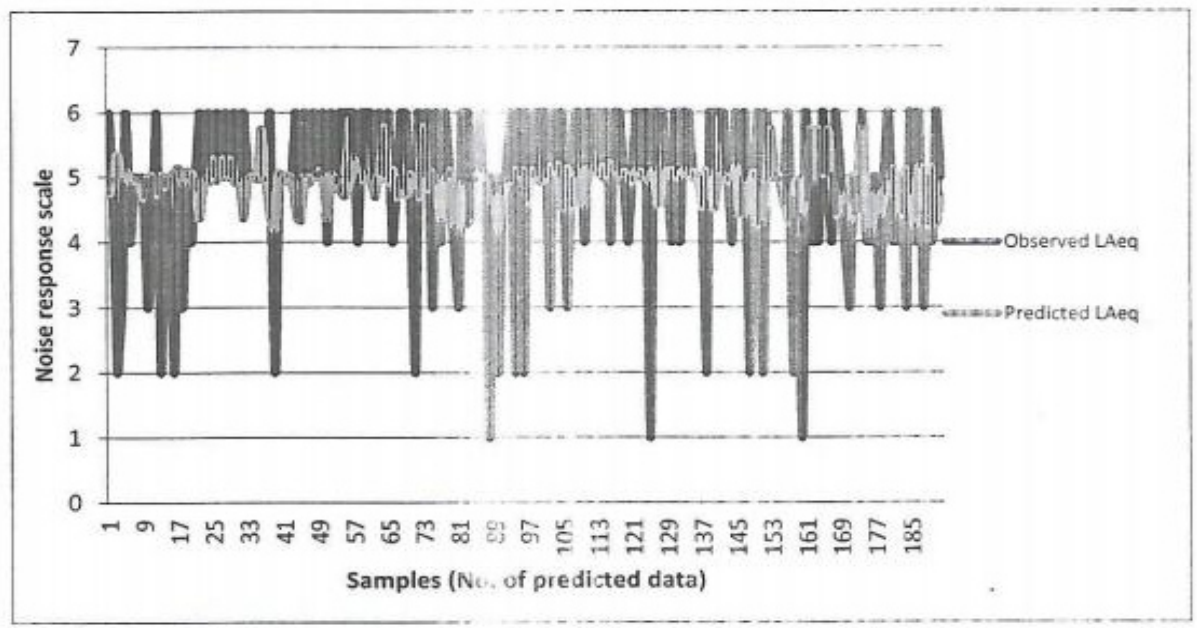

(a) HCA High traffic

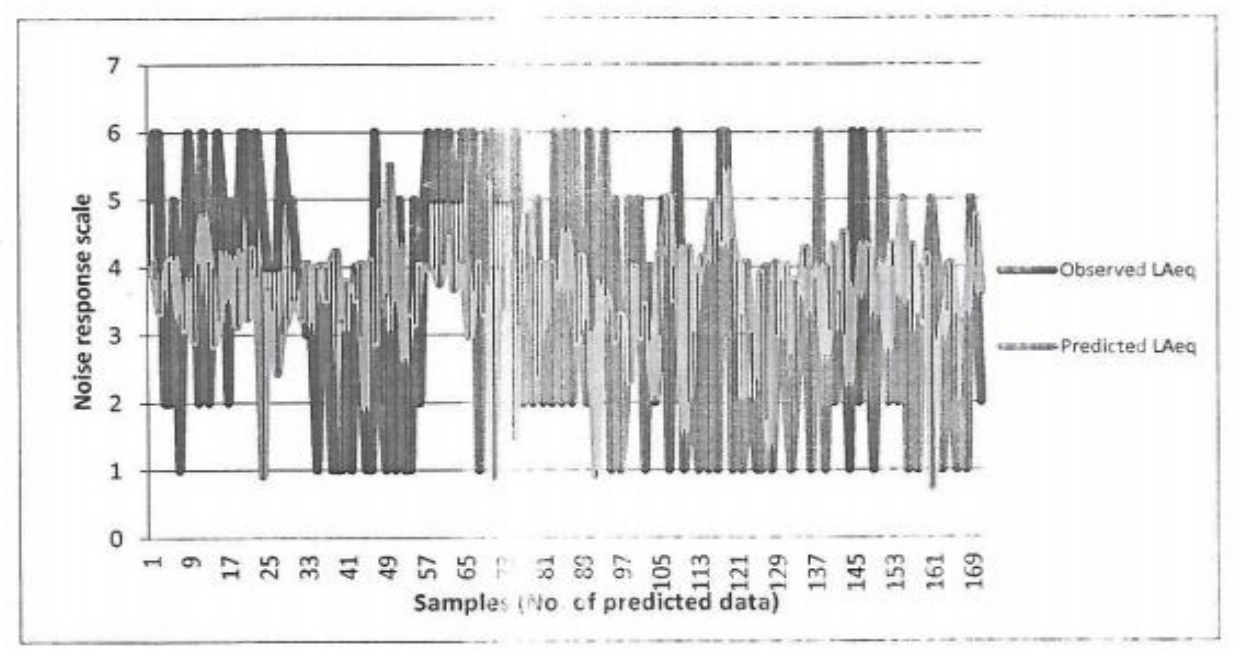

(b) LCA Low traffic

Fig. 3b: Artificial neural network ( $\mathrm{ANN}$ ) model performance curve for checking data for Calabar high and low road iraffic noise pollution sites showing respondents' noise reactions against observed und predicted noise levels. 


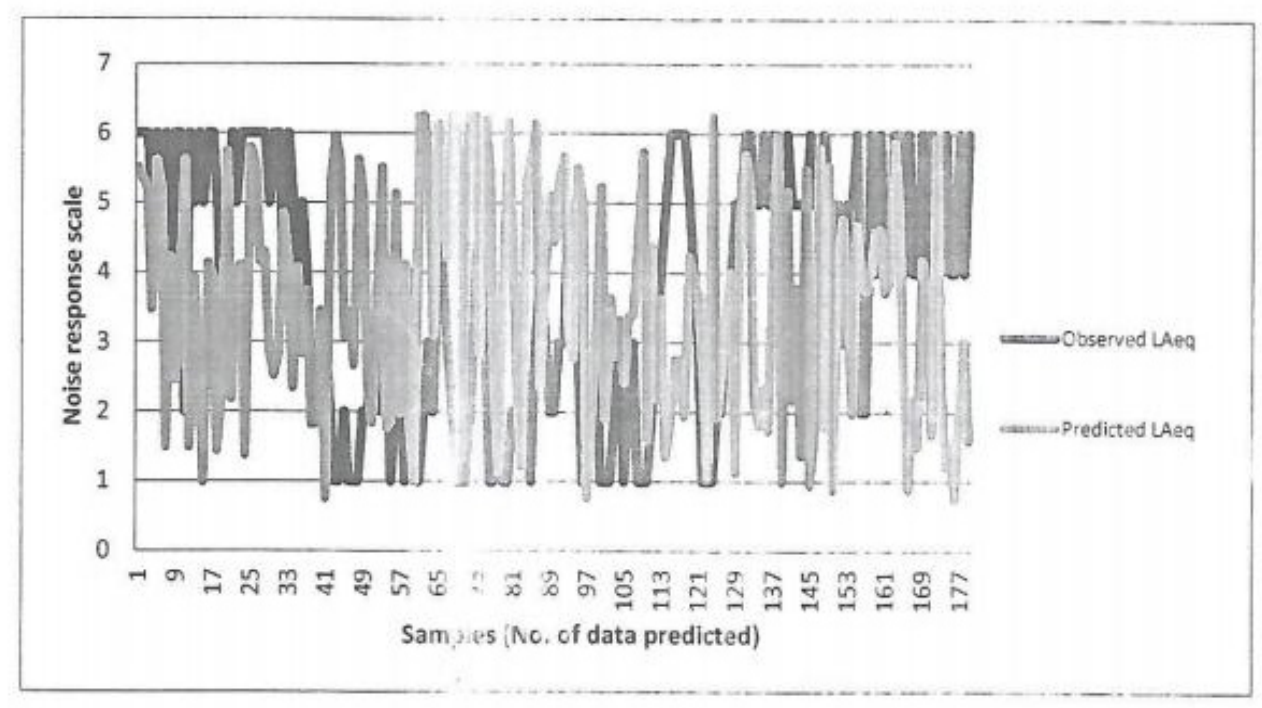

(a) HUY High traffic

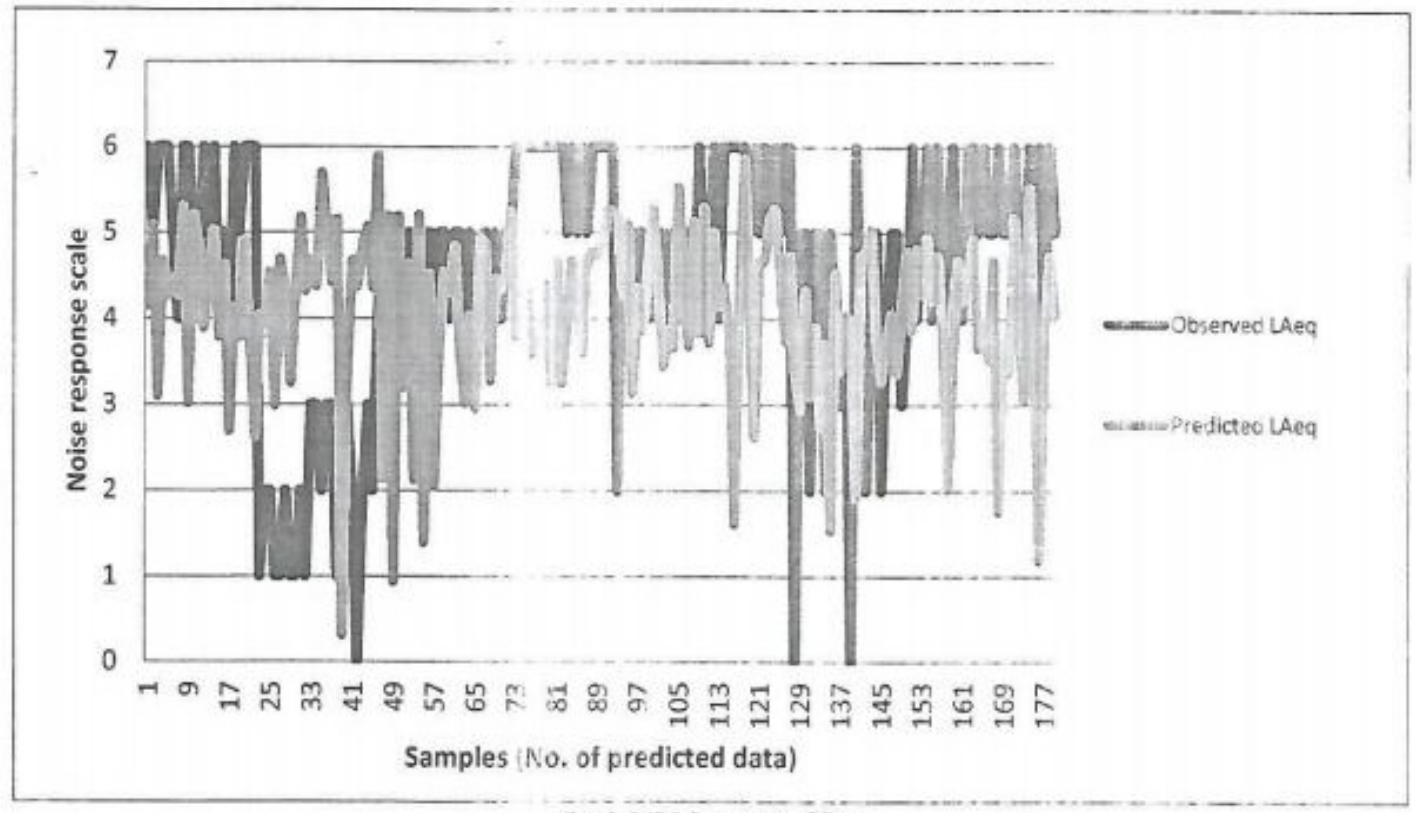

(b) 1.UY Low traftic

Fig. 4b: Artificial neural network (ANN) model performance curve for checking data for Uyo high and low road trafti noise pollution sites showing respondents' noise reactions against observed ind predicted noise levels. 


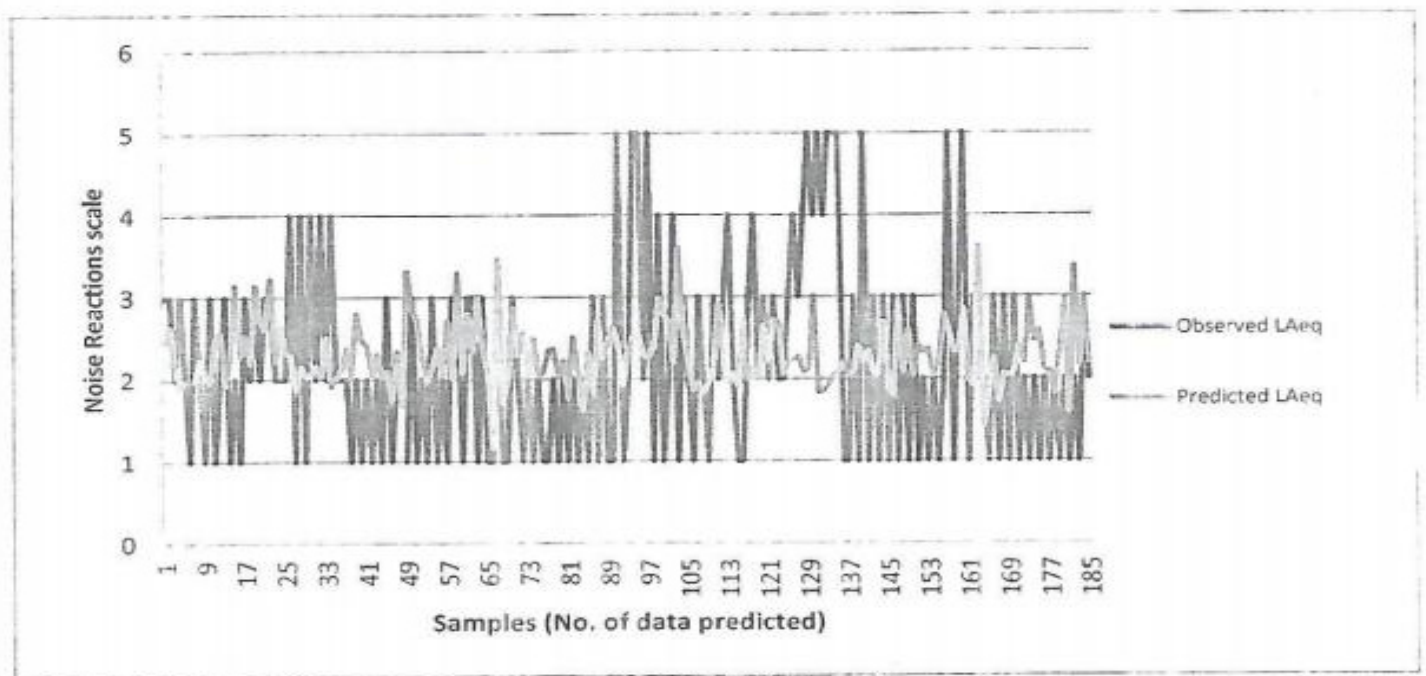

(a) $\overrightarrow{\text { HUM High traffic }}$

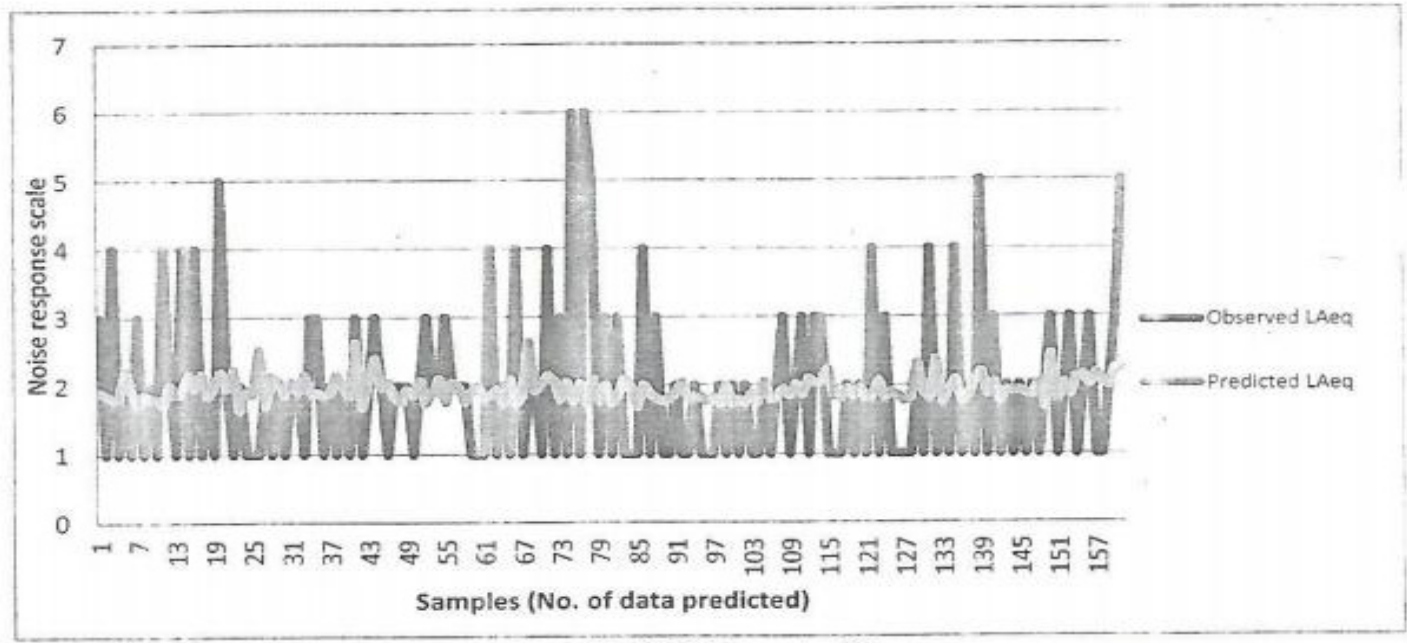

(b) LUM Low traffic

Fig. 5b: Artificial neural network (ANN) model performance curve for checking data for Umuahia high and low road traffic noise pollution sites showing respondents' noise reactions against observed and predicted noise levels. 


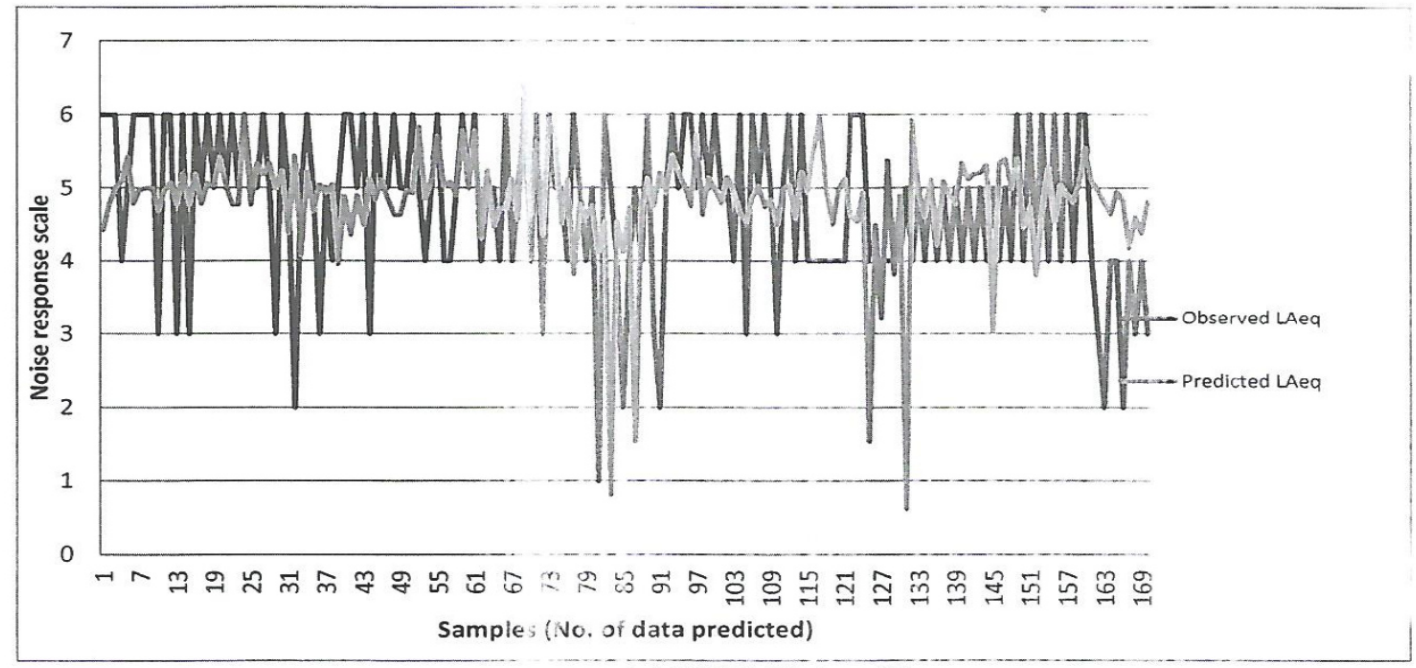

(a) HOW High traffic

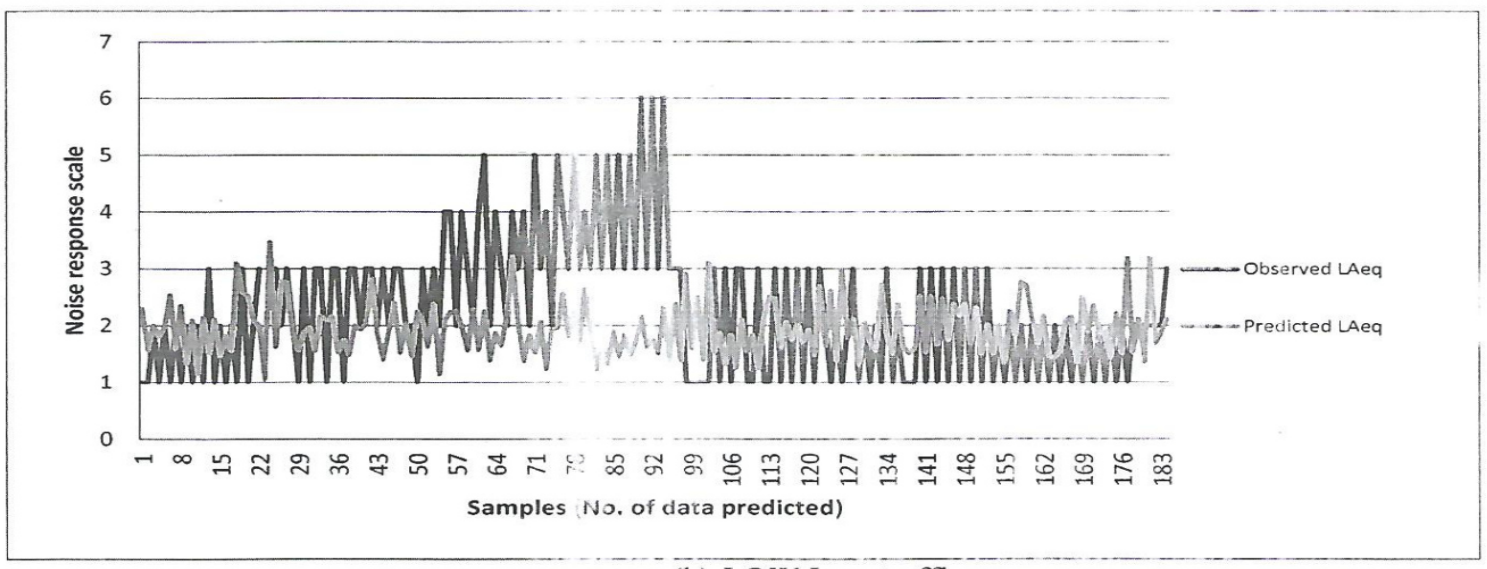

(b) LOW Low traffic

Fig. 6b: Artificial neural network $(\Lambda N N)$ model performance curve for checking data for Owerri high and low road tafic noise pollution sites showing respondents' noise reactions against observed und predicted noise levels. 


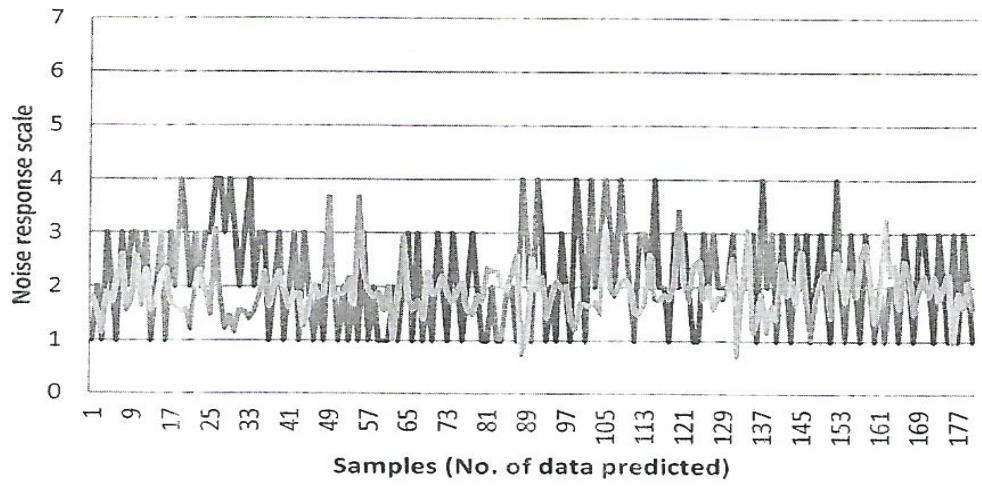

(b) LPH Low traffic

Fig. 7b: Artificial neural network (ANN) model performance curve for checking data for Port Harcourt high and low road traffic noise pollution sites showing respondents" noise reactions against observed and predicted noise levels.

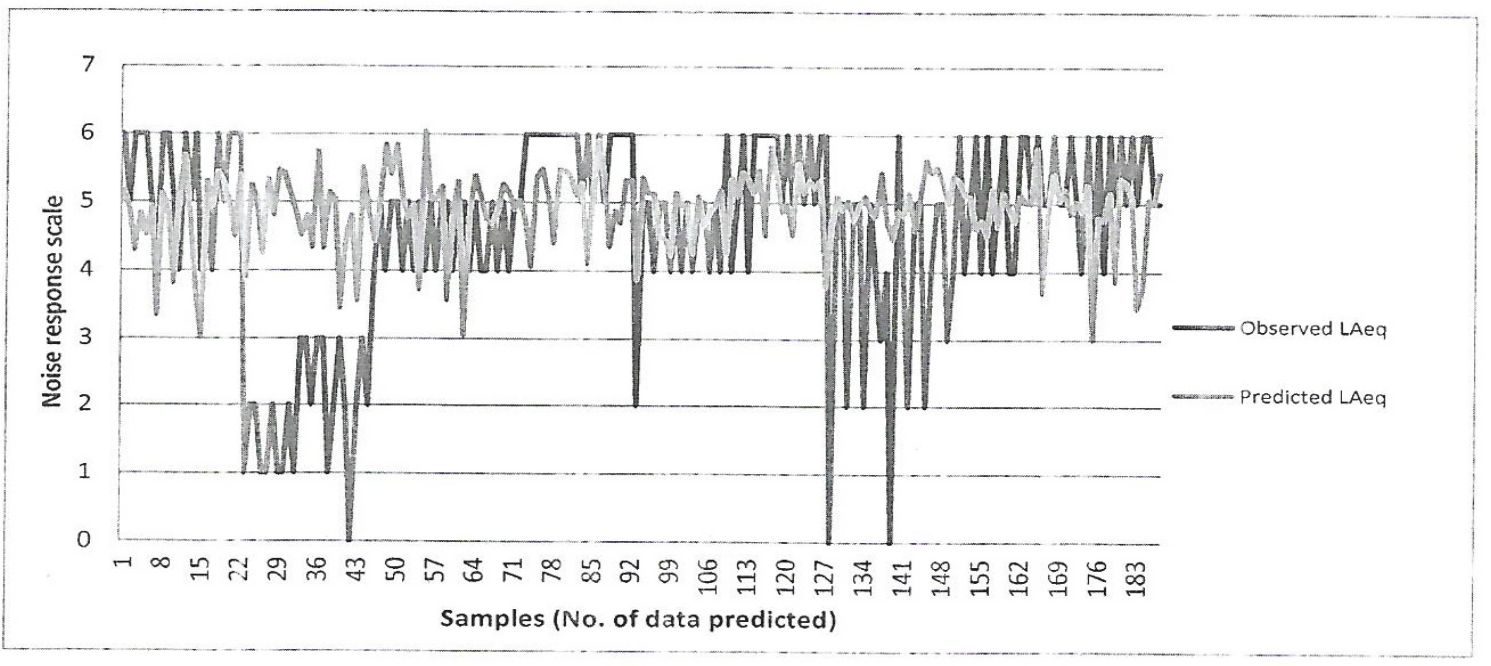

(a) HPH High traffic 